\title{
CAR T cell therapy as a promising approach in cancer immunotherapy: challenges and opportunities
}

Maryam Akhoundi

Royan Institute for Stem Cell Biology and Technology

Mahsa Mohammadi

Royan Institute for Stem Cell Biology and Technology

Seyedeh Saeideh Sahraei

Academic Center for Education Culture and Research

Mohsen Sheykhhasan ( $\square$ mohsen.sh2009@gmail.com)

Hamadan University of Medical Sciences Medical School https://orcid.org/0000-0002-4610-2278

Nashmin Fayazi

Hamadan University of Medical Sciences Medical School

Review

Keywords: CAR T cell therapy, Cancer, Immunotherapy, Adoptive cell transfer

Posted Date: February 9th, 2021

DOI: https://doi.org/10.21203/rs.3.rs-203368/v1

License: (c) (i) This work is licensed under a Creative Commons Attribution 4.0 International License. Read Full License

Version of Record: A version of this preprint was published at Cellular Oncology on March 24th, 2021. See the published version at https://doi.org/10.1007/s13402-021-00593-1. 


\section{Abstract}

Background Chimeric antigen receptor (CAR)-modified T cell therapy has shown great potential in the immunotherapy of patients with hematologic malignancies. In spite of this striking achievement, there are still major challenges to overcome in CAR T cell therapy of solid tumors, including treatmentrelated toxicity and specificity. Also, other obstacles may be encountered in tackling solid tumors, such as their immunosuppressive microenvironment, the heterogeneous expression of cell surface markers, and the cumbersome arrival of T cells at the tumor site. Although several strategies have been developed to overcome these challenges, aditional research aimed at enhancing its efficacy with minimum side effects, the design of precise yet simplified work flows and the possibility to scale-up production with reduced costs and related risks is still warranted.

Conclusions Here, we review main strategies to establish a balance between the toxicity and activity of CAR T cells in order to enhance their specificity and surpass immunosuppression.

In recent years, many clinical studies have been conducted that eventually led to approved products. To date, the FDA has approved two anti-CD19 CAR T cell products for non-Hodgkin lymphoma therapy, i.e., axicbtagene ciloleucel and tisagenlecleucel. With all the advances that have been made in the field of CAR T cell therapy for hematologic malignancies therapy, ongoing studies are focused on optimizing its efficacy and specificity, as well as reducing the side effects. Also, the efforts are poised to broaden CAR T cell therapeutics for other cancers, especially solid tumors.

\section{Introduction}

Cancer immunotherapy is referred to as any form of intervention that forces the immune system to eliminate malignancy. Successful immunotherapy produces anti-cancer immune responses, which are systemic, highly tolerable and overcome the limitations of traditional treatment approaches [1]. Adoptive cell transfer (ACT) is regarded as a novel and efficient immunotherapeutic strategy, especially for cancer treatment [2]. This approach involves the isolation and in vitro expansion of a cancer patient-deriveds activated T lymphocytes and their subsequent reinfusion into cancer patients along with appropriate growth factors to stimulate their in vivo survival and proliferation [2]. It has been shown that the reinfusion of tumor-infiltrating lymphocytes (TILs) may result in cancer regression, but obtaining high-affinity $\mathrm{T}$ cells can be complicated by an immunosuppressive tumor microenvironment. Also, since the accessibility of TILs may be accompanied by technical limitations in at least some tumors, TIL reinfusion is not considered to be fully effective for all tumors [3, 4]. Hence, modification of $\mathrm{T}$ cells towards a highly activated form can be an alternative strategy to efficiently combat various forms of cancers. In recent years, chimeric antigen receptor T cells (CAR T cells) have been introduced to efficiently recognize cancer antigens and to accurately kill tumor cells $[1,5]$.

\section{Car T Cell Therapy}

Chimeric antigen receptors (CARs) are receptor proteins that have been engineered to provide T cells with the ability to target specific proteins. In CAR T cells, the antigen recognition moieties of the engineered receptors are derived from monoclonal antibodies (mAbs). Thus, in addition to the cytolytic efficacy of $T$ cells, CAR structures endow T cells with the enormous diversity and high-affinity/specificity of mAbs against tumor antigens. In addition, CARs can tackle a broad range of candidates for targeting in a major histocompatibility complex (MHC)-independent fashion. In contrast to TILs, this property enables CAR T cells to overcome MHC expression down-regulation by tumor cells (immune escape) [6-8]. In preclinical and clinical CAR T cell studies, various CAR designs are being assessed. These designs mainly involve the antigen-binding domain, the intracellular domain, the transmembrane domain and its spacer (Fig. 1a).

\subsection{Antigen-binding domain}

The extracellular CAR domain recognizes target antigens on tumor cell surfaces and triggers CAR T cell attack. This CAR domain is connected to the transmembrane and intracellular domains by a hinge [9]. In most clinical and preclinical studies, single-chain variable fragments (scFvs) are used in CAR designs as antigen-binding domains. ScFv modules are composed of the reformed variable region of mAbs to the single-chain of heavy and light variable fragments that are connected together in tandem by a flexible linker [9]. In addition to the simple integration of different scFvs in CAR constructs, the use of scFvs as antigen-binding domains enables the targeting of a wide spectrum of antigens with high affinity and specificity. In contrast to traditional T cell receptors, scFvs also enable the targeting of soluble antigens. Therefore, scFvs are beneficial in targeting soluble immunosuppressive molecules present in solid tumor niches, such as transforming growth factor-beta (TGF- $\beta$ ) [10]. On the other hand, the application of scFvs in CAR constructs is complicated by a tendency for oligomerization, which may lead to tonic signaling and T cell exhaustion [11]. Most scFvs that are used in CAR designs are derived from murine models that are potentially reactive towards human anti-mouse antibodies [7]. Replacing human scFvs by their murine forms helps to prevent these effects.

Instead of scFvs, in various studies alternative binding domains have been used for specific functions, such as cytokines [12, 13], peptides [14], Fc receptors [15] and nanobodies [16]. Nanobodies, for instance, are single-domain antibodies that are derived from camelid, comprising the variable regions of heavychain antibodies, leading to higher resistance and lower immunity. In contrast to scFv-based CAR T cells, nanobody-based CAR T cells suffer from fewer encounters with conformational deficiencies. Moreover, their small sizes endows CAR T cells with proper characteristics, thus efficiently infiltrating rigid solid tumor extracellular microenvironments $[17,18]$.

\subsection{Intracellular domain}

The intracellular domain of CARs is commonly composed of two components [19]: (i) a cluster of differentiation 3 (CD3) $\zeta$ chain, which is a necessary component of the intracellular domain and consists of immunoreceptor tyrosine-based activation motifs (ITAMs); these motifs are derived from T cell receptor (TCR) co-receptors and play important roles in signal transduction [20], and (ii) one or more costimulatory domains, which help the complete activation of CAR $\mathrm{T}$ cells and their persistence. Interestingly, the selection of different costimulatory domains is one of the most effective factors determining CAR T cell functioning, metabolism and phenotype [21].

Loading [MathJax]/jax/output/CommonHTML/jax.js 
CD28 and CD4-1BB are the most common costimulatory domains that are used in CAR designs and exhibit dramatic anti-tumor efficacies. CD28 CAR T cells show an effector-like T cell phenotype and a potent cytolytic function. Nevertheless, these cells exhibit a short half-life and a low expansion rate in vivo [22, 23] and are more prone to T cell exhaustion [22]. In contrast, modified T cells with CARs consisting of CD4-1BB emerge as memory-like T cells, which exhibit a high expansion rate and persistence while showing less action severity in vivo [23, 24]. The different behaviors of CD28 and CD4-1BB CAR T cells are attributed to disparate downstream signaling pathways that are triggered by the subsequent activation of $T$ cells [22]. Despite these different functions, CD28 and CD4-1BB CAR T cells do not exhibit significant differences in anti-tumor activities or remission rates in clinical trials [25]. Notably, CD28 and CD4-1BB are not the only costimulatory domains that are used in CAR designs. Several preclinical studies have used other endodomains as costimulatory domains, such as myeloid differentiation primary response 88 (MYD88)/CD40 [26, 27], CD27 [28], CD134 [29, 30], inducible T cell costimulator (ICOS) [31, 32] and DNAX activating protein 12 (DAP12) [33]. As yet, however these alternative costimulatory domains have not been evaluated in patients and, therefore, the efficiencies of these different domains still need to be determined precisely.

\subsection{Transmembrane domain and spacer}

The transmembrane domain normally consists of a hydrophobic alpha-helix, which is usually derived from type I proteins, such as CD3ろ, CD28, CD4 or CD8a [34]. This domain tethers CARs to the cell membrane and connects the antigen-binding site to the intracellular domain and is, therefore, fundamental for CAR surface expression and stability $[35,36]$. The transmembrane components may affect CAR stability, functioning and downstream signaling. CD28 has, for instance, a greater impact on CAR stability than CD3 [37]. Also, CD3 3 may aid CAR-mediated T cell activation due to its role in CAR dimerization and incorporation into endogenous TCRs [35].

In some cases, recognition domains are linked to transmembrane domains by a flexible short peptide fragment as a spacer that is usually derived from CD8, CD28, immunoglobulin G (IgG)1 or IgG4 [34]. Optimal lengths of the spacer provide a balance between the proximity of scFvs and cognate epitopes. They also play an important role in the conformational freedom of CAR receptors for successful attachment [38-40].

\section{Car T Cell Evolution}

Most CAR T cells used in clinical trials can be divided into four generations (Fig. 1b). The first generation of CARs is composed of an extracellular domain along with an intracellular domain, which only consists of $\mathrm{CD} 3 \zeta$. This intracellular domain mediates the signaling cascades after antigen recognition and activation. Since the first generation of CAR T cells encountered deficiencies in their expansion and activity in vivo [11, 41, 42], second and third generation CAR T cells were constructed by adding one or two costimulatory domains, respectively [43-45]. To increase the efficiency of CAR T cells, a fourth generation of CAR T cells, also known as CAR T cell redirected for universal cytokine killing (TRUCK), was developed [18, 36]. In this optimized design, after antigen recognition, CAR T cell activation is followed by cytokine and chemokine induction, leading to self-additional activation. The fourth generation of CAR T cells enables the recruitment and activation of endogenous immune cells and, therefore, their dominance over the immunosuppressive tumor microenvironment (TME) [46]. These CAR T cells were additionally engineered with a nuclear factor of activated T cell (NFAT)-responsive expression cassette (in different genes in the same vector) for the inducible expression of a transgenic cytokine [47]. To date, several cytokines have been adopted into TRUCK designs, including interleukin 12 (IL-12) [48], IL-18 [49] and TNF receptor superfamily member 14 (TNFRSF14).

\section{Challenges And Opportunities}

Despite the advantageous opportunities of CAR T cell therapy, especially in hematological malignancies, several obstacles still limit the general application of this therapeutic strategy. Traditional drug-based cancer therapy depends on general target approaches, while CAR T cell therapy relies on the distinction between cancerous and healthy tissues, as well as on active targeting. However, by not fully reaching this goal, CAR T cell therapy has faced a complex challenge of off-target effects [50] and off-target related toxicity. In addition, true tumor-targeting can lead to CAR T cell over-activation, highly increased cytokine secretion and severe general toxicity. In addition, tumor immune escape has been reported in a considerable number of CAR T cell therapies, and many studies have addressed immune escape with different strategies based on multi-target approaches.

A major challenge in CAR T cell therapy is encountered in patients harboring solid tumors. This challenge can be attributed to several factors, such as lack of suitable tumor-specific antigens, immune-suppressive properties of the TME, tumor heterogeneity, and CAR T cell migration and homing. CAR modifications capable of overcoming these obstacles may extend the therapeutic applications of CAR T cells. Here, some of the challenges and the main implemented strategies in overcoming these obstacles are discussed.

\subsection{Toxicity}

As mentioned above, toxicity is a challenging issue that can be categorized into two clusters: (i) general toxicity as an over-activation-based toxicity and (ii) off-target-based toxicity. General toxicity arises from cytokine secretion at a toxic level, following a robust interaction of CAR T cells and cancer cells. In some cases, intense interaction between CAR T cells and host immune cells results in cross-activation and a cytokine storm that causes toxicity. General toxicity syndromes that occur after CAR T cell therapy include cytokine release syndrome (CRS) [51], immune effector cell-associated neurotoxicity syndrome (ICANS) [52] and, in rare cases, hemophagocytic lymphohistiocytosis (HLH) [53] and macrophage activation syndrome (MAS) [53].

CRS or a cytokine storm is a drastic toxic situation that is frequently observed in patients who have received CAR T cell therapy [15]. This complication is ascribed to expansion and over-activation of CAR T cells, accompanied by a high secretion of various cytokines, such as IL-6, IL-10, interferon-gamma (IFN- $\gamma$ ), tumor necrosis factor-alpha (TNF-a) or granulocyte-macrophage colony-stimulating factor (GM-CSF) by CAR T cells and other immune cells [54]. The severity and kinetics of CRS are influenced by several factors, including overall tumor burden, antigen density, antigen-binding domain affinity and costimulatory factors. For instance, CARs containing CD28 costimulatory domains are, due to their intensive functions, associated with a higher CRS risk than those

Loading [MathJax]/jax/output/CommonHTML/jax.js 
containing CD4-1BB. Hence, it seems that a selection of costimulatory domains must be performed while regarding other risk factors such as tumor burden and antigen density.

CRS symptoms reported in clinical trials have been classified into five grades, ranging from mild to severe toxicity [55]. Fever, myalgia, fatigue and mild hypotension are considered mild CRS symptoms and are manageable by supportive care and by diminishing side effects such as pain. Conversely, hypotension requiring vasopressors, respiratory failure, coagulopathy and multi-organ system failure are considered severe complications of life-threatening and lethal grades of CRS [55]. In order to reduce severe levels of CRS, several strategies have been proposed: (i) sequential cytokine level assessment that can be useful for early detection and inhibition of toxicity progression, (ii) multiple CAR T cell reinfusion with increasing doses, which is advised to control CRS, (iii) use of immunosuppressive drugs such as Tocilizumab (anti-IL-6 receptor), siltuximab (anti-IL-6 antibody) or corticosteroids, administered for CRS suppression and treatment; it must be noted, however, that immunosuppressive drugs can also reduce the functionality of CAR T cells [56] and, therefore, the use of other agents such as IL-1 $\beta$ inhibitors [57], TNF- $\alpha$ inhibitors [58] and GM-CSF inhibitors [59] may be of help to minimize CRS, although their exact efficacy is still elusive, and (iv) the construction of switchable CAR T cells in managing severe toxicity.

Neurotoxicity is another form of prominent toxicity that usually accompanies CRS. The exact mechanism of CAR T cell-associated neurotoxicity has not been elucidated yet [60]. Moreover, it seems that several mechanisms may contribute to the development of neurotoxicity, including passive or active leakage through the blood-brain barrier (BBB) and local accumulation of cytokines and immune cells in the central nervous system [61]. The most common symptoms of ICANS include headache, seizures, delirium, anxiety, tremor, aphasia, decreased consciousness and coma with cerebral edema. In general, mild clinical symptoms are transitory, reversible and self-improvable [62]. In severe situations, IL-6 pathway inhibitors and corticosteroids can be useful in managing neurotoxicity during both the onset of symptoms and at late stages [63]. In more stressful conditions, patients suffering from epilepticus with convulsive or no convulsive status should be treated with benzodiazepines and additional anti-epileptic drugs [63].

\subsection{Immune escape}

In a considerable number of CAR T cell therapies, such as CD19 CAR T cell therapy, fully or partial loss of target antigens on cancer cell surfaces has been reported [64]. This phenomenon can be explained by several mechanisms. One is CD19 loss on the tumor cell surface due to a mutation that leads to alternative splice variants in exon 2 of the CD19 gene, which appears to reduce CD19 cell surface expression [65]. Other studies showed that splice variants in exons 5 and 6 of the CD19 gene lead to a truncated form of CD19 that prevents binding to the target antigen [65, 66]. There exists conflicting information on to whether splice variants are already present [67] or arise as a result of CAR T cell therapy [68]. The presence of CD19 isoforms in some patients with B-cell acute lymphocytic leukemia (B-ALL) suggests another mechanism for antigenic escape [68], i.e., lineage switching from a CD19 + B-ALL tumor cell phenotype to CD19 myeloid cells [69]. In rare cases [70], inaccurate isolation of T cells during the process of CAR T cell production has been found to result in the infusion of CAR molecules into leukemic B cell blasts. During the process of CAR T cell therapy, the expressed CD19 markers on leukemic B cells are masked by their own adjacent anti-CD19 CAR, thus preventing anti-CD 19 CAR T cell attack. Various studies have addressed tumor immune escape using a multi-target approach, some of which will be discussed below.

\subsection{CAR T cell specificity}

Another challenge in CAR T cell immunotherapy is associated with 'on-target, off-tumor' complications (Fig. 3A). In other words, some target antigens do not exhibit an exclusive expression on tumor cells but, instead, exhibit varied levels of expression on normal tissue cells as well [71]. As a result, besides tumor targeting, CAR T cells may also target healthy tissues, leading to adverse effects on vital organs. This complication has also been observed in anti-CD19 CAR T cell therapy, which is approved by the US food and drug administration (FDA). CD19 is also expressed in normal B cells [72]. Therefore, following CD19 CAR $T$ cell therapy, normal CD19+B cells are eradicated, leading to hypogammaglobulinemia. This side effect is manageable with sequential intravenous infusions of immunoglobulin, replacing the eliminated B cell-derived antibodies [72]. In contrast, in other types of cancer, especially solid tumors, 'on-target offtumor' targeting may cause more acute problems and be less tolerable. Off- target-based toxicity has been reported in some CAR T cell therapies against solid tumors, such as CAR T cell therapies targeting human epidermal growth factor receptor 2 (HER2), carbonic anhydrases IX (CAIX) and mesothelin. This issue limits the clinical potential of many CAR T cell products. Therefore, several strategies are being adopted to generate more efficient clinical CAR T cell products that include detecting and implementing antigens with higher specificity to tumor cells, optimizing the interaction of CARs with tumor cells in comparison to healthy cells, and multi-targeting of different tumor-specific antigens that increases the possibility of accurate targeting.

As mentioned above, it appears that CAR-T cell-related toxicity and specificity are the most important challenges that should be addressed. Therefore, several approaches are taken to overcome these issues. Some strategies are being implemented to efficiently control and manage CAR T cell activity and avoid adverse toxicity. Other studies focus on the prevention of CAR T cell activation by undesired targets. Several critical strategies, developed for safety and specificity improvement of CAR T cell therapy, are dealt with in this review.

\section{Car T Cell Activity Management}

Excessive cytokine secretion by CAR T cells limits the clinical efficiency of CAR T cell therapy and increases the possibility of life-threatening side effects. Thus, the discovery of methods that provide opportunities to control the initiation, termination and CAR T cell activity is warranted. To this end, several methods have been developed to manage CAR T cell activity via silencing or eliminating CAR T cells after increased toxicity (Fig. 2).

\subsection{Suicide switchable CAR T cells}

An approach based on a suicide gene represents an off-switch strategy that is suggested to control systems and reduce excessive toxicity of CAR T cells. For this purpose, inducible safety switch segments are integrated into CAR constructs so that chemical factor administration can induce CAR T cell death and elimination. For instance, CAR T cells that are transduced with inducible caspase 9 (iCasp9) safety switches can mediate conditional apoptosis upon

Loading [MathJax]/jax/output/CommonHTML/jax.js zation (CID) [73] (Fig. 2A). This strategy may increase the safety of CAR T cell therapy. However, immediate 
apoptosis induction in most of the modified CAR T cells results in an irreversible termination of CAR T cell therapy and, thus, disease progression [74]. Alternative suicide genes are epitope tags that are recognized by FDA-approved mAbs and induce T cell death through complement-dependent cytotoxicity (CDC) and antibody-dependent cell-mediated cytotoxicity (ADCC). In this approach, programmed CAR T cells express CD20 or truncated epidermal growth factor receptors (EGFRt). The application of associated mAbs, rituximab for CD20 or cetuximab for EGFRt, results in efficient and specific elimination of CAR T cells. Possible on-target side effects arising from mAb binding to normal tissue cells limit further development.

\subsection{Induced functional CAR T cells}

Other strategies may also positively regulate CAR T cell activity. In this case, CAR T cells are activated using exogenous user-provided signals, such as small molecules. The insertion of an inducible gene regulatory system may, for instance, enable controlled expression of CARs upon drug administration, such as tetracycline and doxycycline [75] (Fig. 2C). In this regard, a Tet-On inducible system has been used to control CD19 CAR T cell activity, with a significant antitumor effect in xenograft models [75]. This system allows the reversible control of CAR T cells. However, the relatively slow induction procedure, the partial expression of CARs and some background CAR expression in the absence of inducer molecules may limit the efficacy of this approach. In another strategy, through an induced assembly approach, functional CAR T cells are formed [76]. In this approach, CAR receptors split into two non-functional fragments, one fragment containing the antigen-binding domain and the other containing the activation domain. Each fragment possesses an inducible assembly domain with a binding tendency to the same small molecule. Furthermore, the addition of cognate small molecules assembles the split receptors and provides functional CAR receptors (Fig. 2B) [76]. The limited life span of small molecules restricts prolonged CAR T cell activity in a small molecule-dependent manner, whereas the sequential application of small molecules enables CAR T cell activity.

\subsection{Zip CAR T cells}

Recently, split universal and programmable CARs, which are also known as SUPRA CARs, have been designed to regulate CAR activity. In this system, the CAR segment consists of two moieties: zipCAR and zipFv. Each moiety includes a leucine zipper segment that is attached to a signaling domain in the zipCAR section and to a ligand-binding ScFv domain in the zipFv segment. Vacant zipCAR and zipFv moieties with matched leucine zipper segments are attached, forming a functional CAR T cell (Fig. 2D) [77]. One of the benefits of SUPRA CAR T cells is the capability of controlling CAR T cell activity through external zipFvs. Adding external zipFvs with a complementary structure to the leucine zipper of the original zipFv creates a dimer with zipFv and, thus, inhibits the formation of a functional CAR and its activity. Alternatively, compared to the desired zipFv, the use of external zipFvs at a high density or tendency to the zipCAR segment can lead to domination of a regulatory zipFv over its original, thereby terminating CAR T cell activity (Fig. 2D). This strategy has not only been applied to a safety switch to manage CAR T cell activity, but is also used for either sequential or simultaneous multi-targeting. This approach provides the opportunity to target a panel of antibodies with the same engineered T cells [78]. Different zipFvs can be used without re-administration of CAR T cells, based on the patient's responses during treatment. This method may also be effective for highly heterogeneous solid tumors because of its multi-target capacity [77].

\subsection{Multiple antigen recognition}

Multiple targeting is an effective strategy that allows CAR T cells to discriminate normal cells from tumor cells, thus targeting true tumor cells. This strategy can also be used for surmounting the immune escape of tumor cells. The sequential infusions of different CAR T cells directed against different antigens may be clinically effective. Multi-target CAR T cell therapies can be created by transducing T cells with different CAR constructs, harboring different scFv sequences (Fig. 3B). Also, engineering strategies that produce a single CAR with different targets are being considered.

\subsection{SynNotch CAR T cells}

Synthetic Notch (synNotch), a form of "AND logic gate" system, increases the specificity of CAR T cells by engaging multiple tumor antigens that are needed for full CAR T cell activation. In this system, the binding of "A" antigen to synthetic Notch receptors leads to the release of a Notch transcription factor to the nucleus and the subsequent induction of CAR expression against the "B" antigen (Fig. 3E) $[79,80]$. Therefore, SynNotch CAR T cells are activated in response to a simultaneous recognition of $A$ and $B$ tumor antigens $[79,80]$. In a recent study, engineered T cells with synthetic Notch (synNotch) receptors specific for epithelial cell adhesion molecule (EpCAM) or CD276 that induce receptor tyrosine kinase-like orphan receptor1 (ROR1) CAR expression, were applied to distinguish tumor cells expressing ROR1 from bone marrow stromal cells and splenic stromal cells, also expressing ROR1. The results showed an increase in tumor-cell specificity, reducing the risk of toxicities in animal models [81]. Although this system increases CAR T cell precision, the slow process of CAR T cell activation may limit its efficiency.

\subsection{Split CAR T cells}

In Split CAR T cells, the CAR segment is separated into two non-functional receptors. In each receptor, one antigen-binding domain is accompanied by a costimulatory domain and the other by a CD3Z activation domain (Fig. 3D). In this design, the two receptors target different antigens. Therefore, the CAR T cell activity depends on the simultaneous recognition of both antigens [76]. Preclinical models of both breast [82] and prostate [83] cancer have shown promising results of this approach.

\subsection{Tandem CAR T cells}

Tandem CAR T cells, also known as "OR gates", consist of two scFv domains that are tandemly oriented and work under the same intracellular signaling domain. These antigen-binding sites target different antigens (Fig. 3C). The attachment of each of the binding sites can activate CAR T cells. However, functional synergy and enhanced activation only occur when they are simultaneously engaged [84]. It has also been shown that tandem CAR T cells are more sustainable and less prone to T cell exhaustion and can dominate solid tumor TMEs [85]. Currently, several preclinical studies aimed at using tandem CAR T cells directed against CD19/CD20 and CD19/CD22 for B cell malignancies have been translated into phase 1 clinical trials.

\subsection{CART.BiTE cells}

The bi-specific T cell engagers (BiTEs)-expressing CAR T cells (CART.BiTE cells) approach is designed to tackle major obstacles in immune therapy, such as antigen escape and tumor heterogeneity. BiTEs are a class of engineered bispecific monoclonal antibodies that are formed from two scFvs, which are Loading [MathJax]/jax/output/CommonHTML/jax.js 
connected by a flexible linker. One of the scFvs binds to a particular tumor-associated antigen (TAA), whereas the other forms a specific bond with the invariant component of the TCR complex, CD3 [81]. The simultaneous attachment of BiTEs to CD3 and to a TAA generates an immune synapse between T cells and malignant cells, initiating the cytotoxic activity of T cells against these cells. A new approach combines CARs with BiTEs into a single gene-modified T cell product that co-expresses CAR and BiTE molecules. In this method, a bi-cistronic gene construct containing CAR and BiTE is transferred to T cells to generate CART.BiTEs, i.e., cells with surface CAR expression and BiTE secretion. CAR and BiTE in CART.BiTEs are designed against different antigens, and thus BiTEs secreted from CAR T cells can attach to the T cell receptor of the cell of origin and, thereby, provide multi-targeting ability to CAR T cells. In addition, secreted BiTE may recruit and interact with bystander T cells and employ these cells to act against target cells. Therefore, this method can be beneficial for efficiently targeting heterogeneous solid tumor cell populations and for circumventing their immune escape (Fig. 3G). Currently, this approach is being developed for the treatment of glioblastoma [75], a heterogeneous tumor with numerous overlapping cell clusters that exhibit distinct gene and surface marker expression patterns. Wild-type EGFR is an antigen that is frequently overexpressed in glioblastoma, but it is also expressed in normal tissues. Hence, its targeting may lead to off-target toxicity. EGFR variant III (EGFRvIII) is a mutated antigen expressed in a subset of glioblastomas, but not in non-malignant tissues. Several studies in which EGFRvIll was targeted using anti-EGFRvIII-CD3 BiTE [86] or EGFRvIll directed CAR T cells [87-90] have shown promising results. However, immune escape has also been reported after CAR T cell infusion, due to the heterogeneity of glioblastoma. To address this challenge, CART.BiTEs were developed by generating a bi-cistronic gene construct that permits co-expression of anti-EGFRvIlI CARs and BiTE targeting wild-type EGFR in T cells. By applying this method, not only EGFRvIll positive tumor cells were targeted, but the CAR T cells could also release anti-EGFR BiTEs locally, recruiting and redirecting bystander T cells against tumor outgrowths that expressed wild-type EGFR [75]. Consequently, the aforementioned study showed that these CAR T cells can mediate potent and specific anti-tumor activity against heterogeneous tumor cell populations and mitigate the effect of antigen loss. Undoubtedly, local BiTE secretion enables the targeting of various and/or less specifically expressed antigens [75].

\subsection{Inhibitory CARs}

Another alternative to reduce undesired off-target effects is the application of inhibitory CARs (iCARs). Inhibitory CAR T cells are activated by tumor antigens, whereas normal cells are protected from a CAR T cell-mediated attack. Inhibitory CAR T cells have a receptor for normal cell-specific antigens in addition to their receptors against tumor antigens. The recognition of normal cell-specific antigens by CAR T cells triggers negative signaling endowed by inhibitory domains that have replaced the costimulatory domain (Fig. 3H) [91]. Inhibitory signaling domains are usually derived from inhibitory molecules, such as programmed cell death protein 1 (PD-1) or cytotoxic T lymphocyte-associated protein 4 (CTLA-4). In a preclinical study, it was shown that iCARs feasibly harness natural T cell inhibition exerted by PD-1 and CTLA-4 while protecting normal tissues from off-target effects [92, 93]. Hence, it seems that specific immune checkpoint inhibition of normal tissue antigens can prevent off-target effects. However, a main drawback is that this inhibitory signal can entirely deactivate T cell functionality. In this regard, CD28 is now one of the most commonly used molecules that improves T cell activity via IL-2 secretion [92, 93].

\subsection{Affinity-tuned CAR T cells}

There is a partial overlap in antigens expressed on malignant and non-malignant cells. However, different expression levels between cancer and normal cells can be applied to true-tumor targeting. Affinity-tuned CARs can distinguish tumors with high-density antigen expression from non-malignant cells with lowdensity antigen expression. The higher density of tumor antigens on tumor cells makes them targetable for CARs with lower-affinity scFvs (Fig. 3F) [94]. Therefore, CAR affinity tuning may be a suitable approach for reducing off-tumor toxicity. CAR affinity optimization can be achieved by the introduction of mutations or by recombining heavy and light chains [95]. In a therapeutic study on multiple myeloma (MM), an affinity-tuned CAR T cell approach was used to target CD38 [95]. CD38 is expressed at high levels on all MM cells, and is expressed at low levels on several hematopoietic cells, including natural killer (NK) cells, monocytes and a subset of T cells. In this study, a light-chain exchange technology was used to generate a large panel of scFvs with a wide range of affinities for a CD38 epitope. CAR T cells bearing scFvs derived from low affinity antibodies showed significant anti-tumor cytotoxicities with minimal offtumor effects.

\section{Car T Cell Therapy Limitations For Solid Tumors}

The development of FDA-approved CD19 CAR T cells [96] and the adequate clinical responses observed in hematological malignancies suggest that CAR T cells may also be used as therapeutic candidates for solid tumors [97-99]. However, several complications restrict CAR T cell efficiency in solid tumor therapy (Fig. 4). The successful use of CAR T cell therapy in hematological malignancies is attributed to various factors, including a high expression of surface markers on leukemic cells and an accessibility of immune cells to lymphoid cells. The scarcity of homogeneous tumor-specific antigens is, however, a major obstacle for CAR T cell therapy in solid tumors [100]. Also, several recognized tumor antigens are located inside the cells instead of outside on their surface. Additionally, after intravenous administration, the first hurdle facing CAR T cells is their efficient traveling through the blood stream and homing within the tumor site. Additional barriers include CAR T cell infiltration in the rigid tumor extracellular matrix (ECM), its dominance in the immunosuppressive TME and the persistent activity of T cells. This complexity highlights the need for strategies that improve T cell trafficking, counteract the immunosuppressive TME, enhance the persistence and activity of CAR T cells and, lastly, identify true tumor-specific targets.

\subsection{The absence of definitive markers in solid tumors}

As mentioned above, the identification of specific tumor antigens is a substantial step in the design of CAR T cells. In this respect, solid tumors face more complications because of their intratumoral and intertumoral heterogeneity. Ample research has focused on targeting tumor-associated antigens (TAAs) such as carcinoembryonic antigen (CEA) [101], disialoganglioside GD2 [102], mesothelin [103], interleukin 13 receptor (IL-13R) [104], human epidermal growth factor receptor 2 (HER2) [105] and L1 cell adhesion molecule (L1CAM) [106]. TAAs are overexpressed on tumor cells and exhibit a low expression in normal cells [107]. Thus, their expression may increase the risk of off-tumor toxicity. All of the multi-target approaches discussed above, such as bi-specific CAR T cells, synNotch CAR T cells and switchable forms of CAR T cells, i.e., Zip CARs, are applied to overcome the limitations of specificity and off-tumor toxicity (Fig. 4A). Neoantigens or tumor-specific antigens (TSAs) represent another class of antigens that are considered for targeting in immunotherapy. Neoantigens are Loading [MathJax]/jax/output/CommonHTML/jax.js mutations that occur during tumor development and, thus, are expressed in malignant tissues exclusively. These 
markers are considered as ideal targets for immunotherapy, since they allow the precise targeting of malignant cells without impairing normal cells. Personalized vaccines $[108,109]$ and TIL-based adoptive T cell therapies $[110,111]$ are two main approaches in immunotherapy that target neoantigens and have shown successful results in solid tumors. Several CAR T cell studies regarding neoantigens have been reported [112, 113]. As mentioned above, EGFRvIII is a truncated form of EGFR lacking a significant portion of the extracellular ligand-binding domain, thereby increasing the activity of the ligand-independent component [114]. EGFRvIII is encountered in a high percentage of glioblastomas. This surface neoantigen is specifically expressed on malignant cells at a high level and plays an important role in its tumorigenesis and invasiveness. In a recent clinical trial, anti-EGFRvIll CAR T cells were used against glioblastoma and showed effective results in tumor regression. No evidence for off-tumor toxicity, CRS and/or cross-reactivity to non-mutant EGFR was observed [90, 115, 116]. The majority of the recognized neoantigens are, however, located intracellularly and are immunogenic only when present in a peptide/HLA complex. Hence, for the most part they are not considered as appropriate targets for CAR T cell therapy, since conventional CARs are designed to bind to surface markers in a HLA-independent manner [117]. A recent animal study showed that this drawback can be overcome by implementing scFvs with a targeting ability of epitope/HLA complexes in CAR constructs [118], but the exact efficiency of this approach remains to be determined. In addition, a large fraction of human tumor-associated mutations are not shared between patients at meaningful frequencies and, therefore, they shoul be considered patient-specific. Detecting and targeting patient-specific mutations is, therefore, challenging.

Alternative antigens that prominently affect solid tumor treatment may be derived from the tumor microenvironment rather than from the tumor cells themselves. In contrast to tumor-specific antigens (TSAs), these antigens are shared between solid tumors and are, therefore, not patient-specific [119]. For example, cancer-associated stromal cells (CASCs) that support tumorigenesis and its related angiogenesis are potential candidates for this purpose [120]. Cancer-associated fibroblasts (CAF) represent a subset of CASCs with a significant impact on the immunosuppressive TME. These cells play an important role in tumor progression, metastasis and angiogenesis via the secretion of various cytokines, such as stromal cell-derived factor 1 (SDF1), also known as C-X-C motif chemokine 12 (CXCL12) and vascular endothelial growth factor (VEGF) [120]. Another example is fibroblast activation protein (FAP), which is mainly expressed on CAFs in various solid tumors. It has been reported that CAR T cells directed against FAPs can reduce FAP + fibroblastic cells and decrease extracellular matrix proteins and glycosaminoglycans, thereby effectively facilitating CAR T cell infiltration into the tumor matrix. Many studies have shown the effect of tumor vasculature on the growth of multiple types of cancer $[121,122]$. In a xenograft tumor study, CAR T cells were designed to target VEGFR-1 and the results obtained indicated decreased tumor growth and suppressed pulmonary metastasis [106]. In addition, E3B, a splice variant of fibronectin with expression in the neovascular network of tumors, may serve as a target of CAR T cells with an inhibitory effect on tumor growth [120]. Thus, prevalent microenvironmental factors among various tumors turns them into potential candidates for therapeutic targeting.

\subsection{CAR T cell delivery to the tumor site}

One of the main obstacles in tackling solid tumors is the trafficking of CAR T cells to the tumor site, their infiltration into the tumor parenchyma and their homing. Immune cell trafficking to solid tumors occurs under the guidance of chemotactic signals that are produced by tumor cells or stromal cells in the TME. In response to tumor secreted chemokines, normal T cells do not express adequate chemokine receptors for traveling towards tumor sites [123]. Hence, the insertion of chemokine receptors in CAR T cells helps in sensitizing CAR T cells to chemokine gradients formed by tumoral and/or associated stromal cells (Fig. 4B). The various examples of chemokine receptors in CAR T cell designs include C-C motif chemokine receptor (CCR)2 [124], CCR2b [124, 125], CCR4 [126], C-X-C chemokine receptor (CXCR)1 [127], CXCR2 [128, 129] and CXCR3 [129]. There are, however, some drawbacks regarding the efficiency of these engineered CAR T cells. In inflammation or injury conditions, for example, other organs also produce chemokine gradients that may interfere with CAR T cell trafficking to the tumor site [130]. Also, following CAR T cell trafficking in response to specific chemokine gradients, immune escape may occur due to chemokine loss or down-regulation [130]. In addition, the landscapes of factors secreted by tumors are extremely heterogeneous and vary in both intratumoral sites and between individuals [131].

Another novel strategy for counteracting heterogeneous and inadequate tumor chemokines is inducing the expression of chemokine ligands in tumor cells. Therefore, various intratumoral delivery methods, such as adenoviruses expressing C-C motif chemokine ligand (CCL) 17 [132] or plasmids encoding chemokine ligand CCL5, have been tested [133]. Although no safety obstacles were identified in the intratumoral delivery methods, this approach is not feasible in at least some patients due to inadequate tumor position, technical difficulties and/or complications in identifying metastatic locations. One approach for circumventing the obstacle of T cell infiltration is regional/local CAR T cell administration. Administering CAR T cells directly into the tumor site may also diminish the risk of off-tumor toxicity [134]. Regional delivery appears particularly appealing for CAR T cell therapy of central nervous system (CNS) tumors, due to the safe delivery of CAR T cells into the cerebrospinal fluid. Preclinical studies have also shown that lower doses are needed in this approach, compared to the systemic administration of CAR T cells $[135,136]$. Although direct infusion of CAR T cells has been reported in various anatomical sites, such as brain [137], breast [138] and liver [139], this method is not feasible in some tumors and, in addition, is accompanied by technical limitations. The local CAR T cell infusion approach may be limited to the initial tumor site, without a direct effect on metastatic lesions. Locally infused CAR T cells may, however, initiate and promote endogenous immune responses.

Tissue infiltration of T cells is a multistep process, including the adhesion of molecules on T cells and vasculature cells, and the rolling and the extravasation of circulating T lymphocytes into the tissue [132]. Intercellular adhesion molecule (ICAM) [131], L-selectin [140], vascular cell adhesion protein (VCAM) [141] and other ligands and receptors involved in the aforementioned processes are promising targets for CAR T cell therapy. Physical barriers, including the fibrotic ECM, can impede T cell penetration. Therefore, CAR T cells that induce ECM modifying enzyme expression may facilitate CAR T cell infiltration (Fig. 4C). In an in vivo study it was, for instance, shown that GD2-directed CAR T cells expressing heparinase could degrade heparin sulfate proteoglycans in the ECM, thus enhancing CAR T cell infiltration [142]. In many cases, the physical characteristics of CARs may play an important role. It has been found, for instance, that using nanobodies instead of scFvs can facilitate CAR T cell infiltration into the TME. Nanobody-based CAR T cells only contain the variable fragments of the heavy chains in their antigen-binding site. The small size of the nanobodies helps in penetrating the blood-brain barrier and solid tumor matrixes and in identifying markers that are not accessible for large antibodies [16].

\section{2 Imminno innreccive microenvironments}


After crossing the barriers towards the tumor site, CAR T cells encounter the immunosuppressive TME. Abundant immune suppressor cells including regulatory T cells (Tregs), tumor-associated macrophages (TAMs), tumor-associated neutrophils (TANs) and myeloid-derived suppressor cells (MDSCs) [143] are located in the TME. These cells moderate anti-tumor activity by secreting various immunosuppressive cytokines, such as TGF-B, IL-4, and PD-L1. These factors inhibit immune cell function and activation, thus limiting the therapeutic potential of cancer immunotherapy [144]. A selective depletion of immunosuppressive cells in combination with CAR T cell therapy can increase CAR T cell efficacy [145]. It has been found, for instance, that combination of Treg depletion with systemic CAR T cell therapy enhances anti-tumor activity in preclinical solid tumor models. The efficacy was attributed to decreased immunosuppressive cytokines, including TGF-B, PD-1 and IL-10 that are secreted by Tregs [146]. Depleting MDSCs can also boost CAR T cell responses. In a xenograft sarcoma model, it was shown that the employment of GD2 CART cells together with MDSC depletion led to significant anti-tumor efficacy, whereas CAR T cells alone induced a lower anti-tumor activity [145].

Alternatively, various cytokines secreted by immune cells are considered as suitable targets for CAR T cells. In a recent prostate cancer study, it was shown that engineered prostate-specific membrane antigen (PSMA) CAR T cells that co-express a dominant-negative TGF-RIl exhibited an increased proliferation rate and a long-term in vivo persistence, and could eradicate the tumor [145]. These promising results in preclinical models have led to a clinical trial in patients diagnosed with relapsed and refractory metastatic prostate cancer (NCT03089203).

PD-1 is one of the best characterized immune inhibitory molecules present in the TME. This molecule has been studied as a potential target that can enhance CAR T cell efficacy, Several strategies have been used to manipulate PD-1 expression on CAR T cells: (i) Numerous studies have demonstrated that coadministration of PD-1/PD-L1 blockers with CAR T cell therapy enhances anti-tumor activity and prevents T cell exhaustion in preclinical models [147] and patients receiving mesothelin CAR T cell therapy [141]. Notably, systemic blockade of PD-1/PD-L1 may be accompanied by undesirable effects, generating systemic checkpoint blockade in diseases such as pneumonitis, colitis and hepatitis. Nevertheless, checkpoint inhibition may cause $T$ cell toxicity because of limited T cell safety. (ii) Genetic knockout of PD-1 prevents the adverse side effects of systemic removal of PD-1. The CRISPR/Cas 9 method has been used in several in vitro and in vivo xenograft studies, exhibiting enhanced anti-tumor efficiencies [148]. CTLA-4 [149] and lymphocyte activation gene 3 (LAG3) [150] are other checkpoint molecules that have been efficiently deleted by CRISPR/Cas9, yielding T cells that are less prone to checkpoint inhibition and exhaustion, hence resulting in improved anti-tumor efficacies and persistence in preclinical models. (iii). Armored CAR T cells have been genetically modified to secrete PD1 suppressors at the tumor site. As a result of the PD-1 blockade, increased anti-tumor efficacy was observed (Fig. 4D) [151]. In another approach, the TME can be used against the tumor itself. In other words, modified CAR T cells can switch immune inhibitory signals in the TME to stimulatory signals. For this purpose, the extracellular segments of PD-1 are fused to the costimulatory domains in the CAR design. Subsequent CAR T cell attachment to PDL-1 leads to CAR T cell activation (Fig. 4E) [152]. This approach can be similarly used to convert other inhibitory signals in the TME into proinflammatory signals. Functional CAR T cells have, for instance, been engineered by linking the extracellular portion of inhibitory molecules, such as IL-4 receptors, to the endodomains of proinflammatory cytokines, such as IL-7, IL-2 and IL-15. As a result, immune inhibitory cytokines behave like immune stimulatory agents [153].

In order to subdue the immunosuppressive characteristics of the TME for immune cell activity, several studies have employed armored CAR T cells, also known as TRUCKs, with the capacity to induce several stimulatory cytokines, such as IL-12 [152], IL-7 [154], IL-15 [100] and IL-21 (Fig. 4F) [155]. It was found that these cytokines can enhance CAR T cell immunity by reducing the effects of immunosuppressive agents in the TME, as well as by increasing the expansion and persistence of CAR T cells. In a preclinical model of ovarian cancer, for instance, IL-12-armored CAR T cells were used directed against MUC$16^{\text {ecto }}$ antigen [156,157], resulting in an increase in anti-tumor activity, proliferative capacity, survival and toxicity. These CAR T cells exhibited higher persistence and lower exhaustion. The results obtained in the latter study have led to a clinical trial (NCT02498912) in which IL-12-armored CAR T cells targeted MUC-16 $6^{\text {ecto }}$ are used for the treatment of patients suffering from ovarian cancer [158]. Recently, it has been reported that modified CAR T cells with inducible IL-18 can enhance proinflammatory cytokines and direct immune cell function towards cytotoxicity versus immune-regulatory, thereby decreasing the infiltration and homing of immunosuppressive cells such as Tregs and CD206 + macrophages, and boosting immune attacks [159, 160].

\section{Clinical Car T Cell Manufacturing}

The production of CAR T cells includes several precise steps that start with obtaining peripheral blood mononuclear cells (PBMCs) from patients, commonly via leukapheresis. Subsequently, enriched T cells from the leukapheresis product are activated, transduced by a CAR transgene, and expanded. After successfully passing quality control tests, CAR T cell products are infused into patients. Although the general outline of CAR T cell-based clinical trials are similar, each of the steps involved is carried out by a variety of approaches [161]. Several T cell subsets can be isolated for CAR T cell manufacturing. In the majority of clinical trials, the CD3 + population of T cells is used [44, 162]. In some clinical trials, however, other T cell subsets such as naïve cells [163], memory stem cells [163] and central memory cells [164] have been applied for CAR T cell manufacturing. Different tools, such as CliniMACS, Plus and Prodigy, have enabled the selection of certain subsets of T cells based on different surface markers, such as CD4, CD8, CD25 and CD62L [165]. T cell activation is the next step in CAR T cell manufacturing, which is required for sequential expansion and transduction [165]. Three main methods for T cell activation are used in CAR T cell clinical trials. Monoclonal antibodies, such as anti-CD3, in the presence of various interleukins, such as IL-2 [166], IL-15 [167] and IL-7 [167], can generally activate patient-derived T cells, independent of specific antigens. In some clinical trials, feeder cells, including autologous [45] or allogeneic [168] PBMCs, are used to support T cell activation and expansion. In another approach, artificial antigen-presenting cells (aAPCs), such as K562 cells, are engineered to express co-stimulatory molecules, such as CD32, CD64, CD86 and CD13, on their cell surface to activate T cells [169]. K562 cells lack HLA expression and are, therefore, unlikely to activate alloreactive T cells [170]. A more efficient and potent method, which is frequently used in clinical CAR T cell manufacturing, is independent of antigen presentation and involves stimulation of T cells with paramagnetic $4.5-\mu \mathrm{m}$ diameter beads, which are covalently coated with anti-CD3/anti-CD28 mAbs, along with IL-2 supplementation [171]. The next challenge in CAR T cell manufacturing is successive gene delivery that leads to stable CAR expression. To this end, various viral and non-viral systems for CAR transfer have been developed, including retro- and lentiviral vectors, as well as transposon/transposase and mRNA transfer-mediated gene expression systems [161]. The high transduction efficiency and CAR expression stability allenedlv derived from retrn-or lentiviral transfer systems, seem to be the main reasons why these gene delivery approaches are commonly applied in clinical Loading [MathJax]/jax/output/CommonHTML/jax.js 
CAR T cell manufacturing processes [172]. However, several drawbacks such as cumbersome production scale-up, intensive and expensive good manufacturing practices (GMP) required for production and the risk of oncogenic insertions, restrict the use of viral vectors. Hence, alternatives such as the transposon/transposase system have been evaluated in various studies. In comparison to the viral transfer systems, these systems profit from less complicated manufacturing procedures and are economically advantageous [173]. The main drawback may, however, be the oncogenic nature of the transposon/transposase system. In contrast to stable CAR expression by the viral and transposon/transposase systems, in the CAR mRNA transfection system the relatively short lifespan of mRNA leads to transient cytoplasmic CAR expression. In a mesothelin-targeted CAR T cell therapy study, long-term expression of CAR was provided by sequential infusions of mRNA-transduced CAR T cells [174]. Subsequent injections were carried out in multiple series, followed by toxicity assessments in each step. This approach may be beneficial for toxicity management. To obtain a therapeutic dosage of transduced CAR T cells, they must be expanded. Subsequently, quality control tests must be conducted for checking various criteria, such as identity, safety, purity and potency $[161,165]$.

In addition to the enormous variation mentioned above, one of the most important variations is related to the availability of targetable tumor markers. Due to the heterogeneous character of solid tumors, there are more variations in solid tumor markers than in hematological tumor markers. CD19 is the most common marker in hematological malignancies, which can be tackled by CAR T cell therapy. Additional tumor-related targets are being studied in phases I and Il leukemic clinical trials, including CD20, CD137, CD28, CD33 and B-cell maturation antigen (BCMA). Similarly, various markers such as CD171, PSMA, IL13Ra2, CEACAM5, HER2, GD2, CAIX, mesothelin, EGFRvIII, Claudin 18.2 and NKG2D are being studied in solid tumors (Tables 1 and 2). 
Table 1

Major clinical trials of CAR T cell in solid tumors.

\begin{tabular}{|c|c|c|c|c|c|c|c|c|}
\hline Disease & Target /Construct & $\begin{array}{l}\text { Gene delivery } \\
\text { system }\end{array}$ & Activation & $\begin{array}{l}\text { CAR } \\
\text { generation }\end{array}$ & Response & $\begin{array}{l}\text { Phase/ } \\
\text { Clinical Trials } \\
\text { identifier }\end{array}$ & Toxicity & $\begin{array}{l}\text { Reference/ } \\
\text { Year }\end{array}$ \\
\hline Neuroblastoma & Anti-CD171 & $\begin{array}{l}\text { Plasmid, } \\
\text { electroporation }\end{array}$ & OKT3, IL-2 & I & $\mathrm{Nr}$ & I/ Nr & $\mathrm{Nr}$ & [178]/2007 \\
\hline Neuroblastoma & Anti-GD2 & $\begin{array}{l}\text { Retroviral } \\
\text { transfection }\end{array}$ & OKT3, IL-2 & I & $\mathrm{Nr}$ & I/ NCT00085930 & $\mathrm{Nr}$ & {$[179] / 2011$} \\
\hline Glioblastoma & $\begin{array}{l}\text { Anti-IL13Ra2/ an } \\
\text { interleukin-13 } \\
\text { (E13Y-mutated) } \\
\text { ligand-based CAR } \\
\text { containing a 4-1BB } \\
\text { costimulatory } \\
\text { domain (IL13BBZ), } \\
\text { and truncated } \\
\text { CD19 (CD19t) }\end{array}$ & $\begin{array}{l}\text { Intracranial } \\
\text { injection }\end{array}$ & $\mathrm{Nr}$ & II & $\begin{array}{l}\text { sustained } \\
\text { clinical } \\
\text { response for } \\
7.5 \text { months } \\
\text { after the } \\
\text { initiation of } \\
\text { CAR T-cell } \\
\text { therapy, and } \\
\text { none of } \\
\text { these initial } \\
\text { tumors } \\
\text { (tumors } 1 \\
\text { through } 7 \\
\text { and spinal } \\
\text { tumors) } \\
\text { recurred }\end{array}$ & $\begin{array}{l}\text { I/ } \\
\text { NCT02208362 }\end{array}$ & $\begin{array}{l}\text { No toxic } \\
\text { effects of } \\
\text { grade } 3 \text { or } \\
\text { higher, Grade } \\
1 \text { or } 2 \text { events } \\
\text { were } \\
\text { observed }\end{array}$ & $\begin{array}{l}{[180,181] /} \\
2016\end{array}$ \\
\hline Prostate Cancer & Anti-PSMA & $\begin{array}{l}\text { Retroviral } \\
\text { transfection }\end{array}$ & IL-2 & I & $\begin{array}{l}\text { Two-of-five } \\
(40 \%) \\
\text { patients } \\
\text { achieved } \\
\text { clinical PR, } \\
\text { with PSA } \\
\text { declines of } \\
50 \% \text { and } 70 \% \\
\text { and PSA } \\
\text { delays of } 78 \\
\text { and } 150 \\
\text { days, plus a } \\
\text { minor } \\
\text { response in a } \\
\text { third patient. }\end{array}$ & I/ Nr & $\begin{array}{l}\text { No anti- } \\
\text { PSMA } \\
\text { toxicities } \\
\text { were } \\
\text { observed }\end{array}$ & $\begin{array}{l}{[182] /} \\
2016\end{array}$ \\
\hline Colon cancer & $\begin{array}{l}\text { Anti- ERBB2 (HER- } \\
\text { 2/neu)/ CAR vector } \\
\text { containing CD28, 4- } \\
\text { 1BB, and CD3Z } \\
\text { signaling moieties } \\
\text { was assembled in a } \\
\text { y-retroviral vector } \\
\text { (MSGV1-4D5-CD8- } \\
\text { 28BBZ) }\end{array}$ & $\begin{array}{l}\text { Retroviral } \\
\text { transfection }\end{array}$ & $\begin{array}{l}\text { Anti- } \\
\text { CD3 mAb } \\
\text { and } \\
\text { interleukin-2 } \\
\text { (IL-2) }\end{array}$ & III & $\begin{array}{l}\text { Increases in } \\
\text { interferon-y } \\
\text { (IFN-y), } \\
\text { granulocyte } \\
\text { macrophage- } \\
\text { colony } \\
\text { stimulating } \\
\text { factor (GM- } \\
\text { CSF), tumor } \\
\text { necrosis } \\
\text { factor-a } \\
\text { (TNF-a), } \\
\text { interleukin-6 } \\
\text { (IL-6), and IL- } \\
\text { 10, } \\
\text { consistent } \\
\text { with a } \\
\text { cytokine } \\
\text { storm }\end{array}$ & $\begin{array}{l}\text { I/II / NCl-09-C- } \\
0041\end{array}$ & $\begin{array}{l}\text { Patient was } \\
\text { died }\end{array}$ & $\begin{array}{l}{[183] /} \\
2010\end{array}$ \\
\hline $\begin{array}{l}\text { CEACAM5 + } \\
\text { tumors }\end{array}$ & $\begin{array}{l}\text { Anti-CEACAM5 / } \\
\text { CEACAM5-specific } \\
\text { scFv (MFE23) } \\
\text { fused to CD3 }\end{array}$ & $\begin{array}{l}\text { Antibody- } \\
\text { directed pro- } \\
\text { drug therapy } \\
\text { strategies }\end{array}$ & IL2 & I & $\begin{array}{l}\text { No objective } \\
\text { clinical } \\
\text { responses } \\
\text { were } \\
\text { observed }\end{array}$ & I/ NCT01212887 & $\begin{array}{l}\text { Respiratory } \\
\text { toxicity was } \\
\text { observed }\end{array}$ & $\begin{array}{l}{[184] /} \\
2017\end{array}$ \\
\hline $\begin{array}{l}\text { Renal cell } \\
\text { carcinoma }\end{array}$ & $\begin{array}{l}\text { Anti- carboxy- } \\
\text { anhydrase-IX } \\
\text { (CAIX) }\end{array}$ & $\begin{array}{l}\text { Retroviral } \\
\text { transfection }\end{array}$ & $\begin{array}{l}\text { human } \\
\text { recombinant } \\
\text { interleukin-2 }\end{array}$ & I & $\begin{array}{l}\text { No clinical } \\
\text { responses } \\
\text { were } \\
\text { observed }\end{array}$ & $\begin{array}{l}\text { I/ DDHK97- } \\
\text { 29/P00.0040C }\end{array}$ & $\begin{array}{l}\text { no liver } \\
\text { toxicities } \\
\text { were } \\
\text { observed }\end{array}$ & $\begin{array}{l}{[185] /} \\
2013\end{array}$ \\
\hline $\begin{array}{l}\text { Colorectal } \\
\text { cancer }\end{array}$ & $\begin{array}{l}\text { Anti-NKG2D } \\
\text { receptor/ NKG2D } \\
\text { ligand and TCR } \\
\text { signaling }\end{array}$ & $\begin{array}{l}\text { Retroviral } \\
\text { transfection }\end{array}$ & $\mathrm{Nr}$ & $\mathrm{Nr}$ & $\mathrm{Nr}$ & I/ NCT03310008 & $\begin{array}{l}\text { Grade3/4 } \\
\text { related AE } \\
\text { and graft- } \\
\text { versus-host } \\
\text { disease } \\
\text { (GvHD) } \\
\text { occurrence } \\
\text { were } \\
\text { observed }\end{array}$ & $\begin{array}{l}{[186] /} \\
2019\end{array}$ \\
\hline
\end{tabular}




\begin{tabular}{|c|c|c|c|c|c|c|c|c|}
\hline Disease & Target /Construct & $\begin{array}{l}\text { Gene delivery } \\
\text { system }\end{array}$ & Activation & $\begin{array}{l}\text { CAR } \\
\text { generation }\end{array}$ & Response & $\begin{array}{l}\text { Phase/ } \\
\text { Clinical Trials } \\
\text { identifier }\end{array}$ & Toxicity & $\begin{array}{l}\text { Reference/ } \\
\text { Year }\end{array}$ \\
\hline $\begin{array}{l}\text { Pancreatic } \\
\text { ductal } \\
\text { adenocarcinoma }\end{array}$ & Anti-Mesothelin & $\begin{array}{l}\text { mRNA } \\
\text { electroporation }\end{array}$ & $\mathrm{Nr}$ & $\mathrm{Nr}$ & $\begin{array}{l}\text { The total } \\
\text { metabolic } \\
\text { active } \\
\text { volume } \\
\text { (MAV) } \\
\text { remained } \\
\text { stable in } 3 \\
\text { patients and } \\
\text { decreased by } \\
69.2 \% \text { in } 1 \\
\text { patient. In } \\
\text { this patient, } \\
\text { all liver } \\
\text { lesions had a } \\
\text { complete } \\
\text { reduction in } \\
\text { FDG uptake } \\
\text { at } 1 \text { month, } \\
\text { there was no } \\
\text { effect on the } \\
\text { primary } \\
\text { PDAC. }\end{array}$ & I/ Nr & $\begin{array}{l}\text { None of the } \\
\text { patients } \\
\text { developed } \\
\text { CRS or } \\
\text { neurologic } \\
\text { symptoms } \\
\text { and there } \\
\text { were no } \\
\text { dose-limiting } \\
\text { toxicities. }\end{array}$ & $\begin{array}{l}{[187] /} \\
2018\end{array}$ \\
\hline $\begin{array}{l}\text { Recurrent } \\
\text { glioblastoma }\end{array}$ & $\begin{array}{l}\text { Anti- the epidermal } \\
\text { growth factor } \\
\text { receptor variant III } \\
\text { (EGFRvIIII)/ a } \\
\text { lentiviral construct } \\
\text { with 4-1BB } \\
\text { costimulatory } \\
\text { domain ( } \\
\text { humanized anti- } \\
\text { EGFRvIll single- } \\
\text { chain variable } \\
\text { fragment fused to } \\
\text { the hinge and } \\
\text { transmembrane } \\
\text { domain of CD8 and } \\
\text { the human 4-1BB } \\
\text { and CD3Z } \\
\text { intracellular } \\
\text { signaling domains) }\end{array}$ & $\begin{array}{l}\text { Intravenous } \\
\text { infusion }\end{array}$ & $\mathrm{Nr}$ & $\|$ & $\mathrm{Nr}$ & I/ NCT02209376 & $\begin{array}{l}\text { No subjects } \\
\text { experienced } \\
\text { evidence of } \\
\text { EGFR- } \\
\text { directed } \\
\text { toxicity or } \\
\text { systemic } \\
\text { CRS }\end{array}$ & $\begin{array}{l}{[188] /} \\
2017\end{array}$ \\
\hline $\begin{array}{l}\text { Recurrent } \\
\text { ovarian cancer }\end{array}$ & $\begin{array}{l}\text { Anti- MUC-16 ecto/ } \\
\text { 4H11 CAR } \\
\\
\text { Binding Domain } \\
\text { and MUC16 ecto ( } \\
\text { 4H11-28z/fIL- } \\
\text { 12/EFGRt) }\end{array}$ & $\begin{array}{l}\text { intravenous } \\
\text { and } \\
\text { intraperitoneal } \\
\text { injection }\end{array}$ & IL-12 & II & $\mathrm{Nr}$ & I/ & $\begin{array}{l}\text { Severe CRS } \\
\text { was } \\
\text { observed }\end{array}$ & $\begin{array}{l}{[189] /} \\
2015\end{array}$ \\
\hline Glioblastoma & $\begin{array}{l}\text { Anti-EGFRvIll// } \\
\text { EGFRvIlI CAR } \\
\text { containing CD28 } \\
\text { and } 4-1 \mathrm{BB} \\
\text { costimulatory } \\
\text { domains, and CD3ろ } \\
\text { signaling domain }\end{array}$ & $\begin{array}{l}\text { Intravenous } \\
\text { injection }\end{array}$ & IL-12 & III & $\begin{array}{l}\text { One patient } \\
\text { with survival } \\
\text { of } 59 \text { months }\end{array}$ & I/ & $\begin{array}{l}\text { Two patients } \\
\text { experienced } \\
\text { severe } \\
\text { hypoxia. }\end{array}$ & $\begin{array}{l}{[190] /} \\
2019\end{array}$ \\
\hline Glioblastoma & 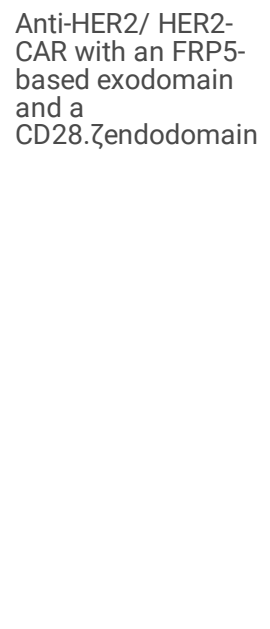 & $\begin{array}{l}\text { Intravenous } \\
\text { injection }\end{array}$ & IL-2 & II & $\begin{array}{l}\text { One PR was } \\
\text { observed. } \\
\text { Eight } \\
\text { Patients had } \\
\text { a clinical } \\
\text { benefit, with } \\
\text { a median } \\
\text { overall } \\
\text { survival of } \\
11.1 \text { Months } \\
\text { after T-cell } \\
\text { infusion and } \\
24.5 \text { months } \\
\text { after } \\
\text { diagnosis, } \\
\text { and } 3 \\
\text { patients were } \\
\text { alive with no } \\
\text { disease } \\
\text { progression } \\
\text { at the last } \\
\text { follow-up. }\end{array}$ & NCT01109095 & $\begin{array}{l}\text { This } \\
\text { phase1dose- } \\
\text { escalation } \\
\text { study } \\
\text { established } \\
\text { the safety of } \\
\text { autologous } \\
\text { HER2-CAR T } \\
\text { in17 patients } \\
\text { with } \\
\text { Progressive } \\
\text { glioblastoma } \\
\text { with no } \\
\text { serious AE. }\end{array}$ & $\begin{array}{l}{[191] /} \\
2017\end{array}$ \\
\hline
\end{tabular}




\begin{tabular}{|c|c|c|c|c|c|c|c|c|}
\hline Disease & Target /Construct & $\begin{array}{l}\text { Gene delivery } \\
\text { system }\end{array}$ & Activation & $\begin{array}{l}\text { CAR } \\
\text { generation }\end{array}$ & Response & $\begin{array}{l}\text { Phase/ } \\
\text { Clinical Trials } \\
\text { identifier }\end{array}$ & Toxicity & $\begin{array}{l}\text { Reference/ } \\
\text { Year }\end{array}$ \\
\hline Breast Cancer & $\begin{array}{l}\text { Anti-c-Met/ c-Met, } \\
\text { BBZ CAR construct }\end{array}$ & $\begin{array}{l}\text { Intratumoral } \\
\text { injection }\end{array}$ & $\mathrm{Nr}$ & ॥ & $\begin{array}{l}\text { Intratumoral } \\
\text { injections of } \\
\text { mRNA c-Met- } \\
\text { CAR T cells } \\
\text { are well } \\
\text { tolerated and } \\
\text { evoke an } \\
\text { inflammatory } \\
\text { response } \\
\text { within } \\
\text { tumors. }\end{array}$ & $\begin{array}{l}\text { O/ } \\
\text { NCT01837602 }\end{array}$ & $\begin{array}{l}\text { None of the } \\
\text { patients had } \\
\text { study drug- } \\
\text { related AE } \\
\text { greater than } \\
\text { grade } 1 .\end{array}$ & $\begin{array}{l}{[192] /} \\
2017\end{array}$ \\
\hline $\begin{array}{l}\text { Metastatic lung } \\
\text { and breast } \\
\text { cancers }\end{array}$ & $\begin{array}{l}\text { Anti-Mesothelin/ } \\
\text { CD28-costimulated } \\
\text { MSLN CAR T cells } \\
\text { with the I-caspase-9 } \\
\text { safety gene }\end{array}$ & $\begin{array}{l}\text { Intra pleural } \\
\text { injection }\end{array}$ & $\mathrm{Nr}$ & ॥ & $\begin{array}{l}\text { Best } \\
\text { responses } \\
\text { included } 2 \\
\text { patients with } \\
\text { the complete } \\
\text { metabolic } \\
\text { response on } \\
\text { PET (62 and } \\
39 \text { weeks } \\
\text { ongoing); } 5 \\
\text { PR }\end{array}$ & I/ & $\begin{array}{l}\text { No CAR T- } \\
\text { cell-related } \\
\text { toxicities } \\
\text { higher than } \\
\text { grade } 1 \text { were } \\
\text { observed. } 1 \\
\text { patient } \\
\text { developing } \\
\text { grade } 3 \\
\text { pneumonitis }\end{array}$ & $\begin{array}{l}{[193] /} \\
2019\end{array}$ \\
\hline $\begin{array}{l}\text { Metastatic } \\
\text { Colorectal } \\
\text { Cancers }\end{array}$ & $\begin{array}{l}\text { Anti- CEA+/ } \\
\text { BW431/26 } \\
\text { scFvlgG4 hinge- } \\
\text { CD28 } \\
\text { transmembrane } \\
\text { domain-CD28-CD3z }\end{array}$ & $\begin{array}{l}\text { Plasmid } \\
\text { transfection }\end{array}$ & IL-2 & II & $\begin{array}{l}\text { Most } \\
\text { patients had } \\
\text { an apparent } \\
\text { decrease in } \\
\text { the CEA } \\
\text { levels as } \\
\text { response to } \\
\text { CAR-T } \\
\text { therapy, } \\
\text { especially in } \\
\text { long-term } \\
\text { observation. }\end{array}$ & I/ & $\begin{array}{l}\text { Severe AE } \\
\text { related to } \\
\text { CAR-T } \\
\text { therapy were } \\
\text { not } \\
\text { observed. Of } \\
\text { the } 10 \\
\text { patients, } 7 \\
\text { patients who } \\
\text { experienced } \\
\text { PD in } \\
\text { previous } \\
\text { treatments } \\
\text { had stable } \\
\text { disease after } \\
\text { CAR-T } \\
\text { therapy }\end{array}$ & $\begin{array}{l}{[194] /} \\
2017\end{array}$ \\
\hline
\end{tabular}


Table 2

Major clinical trials of CAR T cells in hematological malignancies.

\begin{tabular}{|c|c|c|c|c|c|c|c|c|}
\hline Disease & $\begin{array}{l}\text { Target } \\
\text { /Construct }\end{array}$ & $\begin{array}{l}\text { Gene delivery } \\
\text { system }\end{array}$ & Activation & $\begin{array}{l}\text { CAR } \\
\text { generation }\end{array}$ & Response & $\begin{array}{l}\text { Phase/ } \\
\text { Clinical Trials. } \\
\text { gov identifier }\end{array}$ & Toxicity & $\begin{array}{l}\text { Reference/ } \\
\text { Years }\end{array}$ \\
\hline MCL & $\begin{array}{l}\text { CD20/Plasmid } \\
\text { Vector including } \\
\text { a CD20-specific } \\
\text { chimeric T-cell } \\
\text { receptor and } \\
\text { neomycin } \\
\text { resistance gene }\end{array}$ & Electroporation & $\begin{array}{l}\text { OKT3, IL-2, } \\
\text { irr.all. PBMCs, } \\
\text { LCL }\end{array}$ & $1 \mathrm{st}$ & $\begin{array}{l}28.57 \% \\
\text { maintained } \\
\text { a previous } \\
\text { complete } \\
\text { response } \\
14.29 \% \\
\text { achieved a } \\
\text { partial } \\
\text { response } \\
57.14 \% \\
\text { stable } \\
\text { disease }\end{array}$ & $\begin{array}{l}\text { I/ } \\
\text { NCT00012207 }\end{array}$ & $\begin{array}{l}25 \% \text { a flulike } \\
\text { syndrome, } 25 \% \\
\text { fever, skin } \\
\text { reactions at } \\
\text { injection site, } \\
\text { chills, myalgias, } \\
\text { dyspnea, } \\
\text { dysgeusia, } \\
\text { malaise or fatigue, } \\
\text { diaphoresis, and } \\
\text { injection site } \\
\text { reactions was } \\
\text { observed }\end{array}$ & $\begin{array}{l}{[195] /} \\
2008\end{array}$ \\
\hline AML & $\begin{array}{l}\text { CD33/Lentiviral } \\
\text { vector harboring } \\
\text { anti-CD33 scFv, } \\
\text { human CD8a } \\
\text { hinge and } \\
\text { transmembrane } \\
\text { domains, and } \\
\text { human 4-1BB } \\
\text { and CD3ろ } \\
\text { signaling } \\
\text { domains }\end{array}$ & $\begin{array}{l}\text { Lentivirus } \\
\text { vector }\end{array}$ & $\begin{array}{l}\text { antihuman CD3 } \\
\text { monoclonal } \\
\text { antibody, } \\
\text { recombinant } \\
\text { human IL-2, } \\
\text { recombinant } \\
\text { human } \\
\text { interferon (IFN)- } \\
\text { Y }\end{array}$ & $1 \mathrm{st}$ & $\mathrm{Nr}$ & $\begin{array}{l}\text { I/II/ } \\
\text { NCT01864902 }\end{array}$ & $\begin{array}{l}\text { The CART-33 } \\
\text { infusion alone } \\
\text { induced rigorous } \\
\text { chills and fevers; } \\
\text { drastic } \\
\text { fluctuations of his } \\
\text { preexisting } \\
\text { pancytopenia; } \\
\text { elevated serum } \\
\text { cytokine levels, } \\
\text { including IL-6, IL-8, } \\
\text { tumor necrosis } \\
\text { factor-a, and } \\
\text { interferon-y; slight } \\
\text { transient } \\
\text { hyperbilirubinemia } \\
\text { within } 2 \text { weeks } \\
\text { was observed. } \\
\text { a subsequent } \\
\text { intermittent } \\
\text { moderate fever; } \\
\text { and reversed } \\
\text { fluctuation of the } \\
\text { pancytopenia was } \\
\text { observed. }\end{array}$ & $\begin{array}{l}{[196] /} \\
2015\end{array}$ \\
\hline DLBCL & $\begin{array}{l}\text { CD19/ } \\
\text { Lentivirus } \\
\text { vector harboring } \\
\text { anti-CD19 scFv, } \\
\text { human 4-1BB } \\
\text { and CD3ろ } \\
\text { signaling } \\
\text { domains }\end{array}$ & $\begin{array}{l}\text { Lentiviral } \\
\text { vector }\end{array}$ & $\mathrm{Nr}$ & $2 \mathrm{st}$ & $\begin{array}{l}82 \% \text { OR, } \\
73 \% \text { CR, } 9 \% \\
\text { PR and } 18 \% \\
\text { PD }\end{array}$ & I/ & $\begin{array}{l}\text { One DLBCL } \\
\text { patient in CR had } \\
\text { a parenchymal } \\
\text { brain lesion in the } \\
\text { right temporal } \\
\text { lobe that also } \\
\text { completely } \\
\text { resolved. } \\
\text { Of note, this } \\
\text { patient had no } \\
\text { CRS or } \\
\text { neurotoxicity } \\
\text { associated with } \\
\text { JCAR017 } \\
\text { treatment }\end{array}$ & $\begin{array}{l}{[197] /} \\
2016\end{array}$ \\
\hline
\end{tabular}




\begin{tabular}{|c|c|c|c|c|c|c|c|c|}
\hline Disease & $\begin{array}{l}\text { Target } \\
\text { /Construct }\end{array}$ & $\begin{array}{l}\text { Gene delivery } \\
\text { system }\end{array}$ & Activation & $\begin{array}{l}\text { CAR } \\
\text { generation }\end{array}$ & Response & $\begin{array}{l}\text { Phase/ } \\
\text { Clinical Trials. } \\
\text { gov identifier }\end{array}$ & Toxicity & $\begin{array}{l}\text { Reference/ } \\
\text { Years }\end{array}$ \\
\hline DLBCL & $\begin{array}{l}\text { CD19/Lentivirus } \\
\text { vector harboring } \\
\text { anti-CD19 sCFv, } \\
\text { human 4-1BB } \\
\text { and CD3乙 } \\
\text { signaling } \\
\text { domains }\end{array}$ & $\begin{array}{l}\text { Lentiviral } \\
\text { vector }\end{array}$ & $\mathrm{Nr}$ & $2 \mathrm{st}$ & $\begin{array}{l}\text { Among } \\
\text { patients } \\
\text { evaluable } \\
\text { for efficacy } \\
\text { ( } n=255) \text {, } \\
\text { ORR was } \\
73 \%(95 \% \text { Cl, } \\
67-78) \\
\text { the CR rate } \\
\text { was 53\% } \\
\text { (95\% Cl, 47- } \\
59) \text {. } \\
\text { Responses } \\
\text { were similar } \\
\text { across all } \\
\text { patients } \\
\text { subgroups. } \\
\text { Median DOR } \\
\text { was 13.3 } \\
\text { months } \\
\text { (95\% Cl, } \\
8.2-\text { not } \\
\text { reached } \\
\text { [NR]) with } \\
\text { 10.8 mo of } \\
\text { median } \\
\text { follow-up. } \\
\text { Median DOR } \\
\text { for patients } \\
\text { in CR was } \\
\text { NR (13.3- } \\
\text { NR). Median } \\
\text { PFS was 6.8 } \\
\text { months } \\
\text { (95\% Cl, } \\
3.3-11.8 \text { ). }\end{array}$ & ' NCT02631044 & $\begin{array}{l}\text { Safety analysis } \\
\text { showed } 79 \% \text { of } \\
\text { patients had } \\
\text { grade } \geq 3 \mathrm{AEs} \text {, } \\
\text { primarily } \\
\text { cytopenias } \\
\text { (neutropenia, } 60 \% \text {; } \\
\text { anemia, } 37 \% \text {; } \\
\text { thrombocytopenia, } \\
27 \% \text { ). } \\
\text { CRS or NE } \\
\text { occurred in } 47 \% \text { of } \\
\text { patients was } \\
\text { observed. } \\
\text { Any grade CRS } \\
\text { occurred in } 42 \% \text { of } \\
\text { patients at a } \\
\text { median onset of } 5 \\
\text { days; only } 2 \% \text { had } \\
\text { grade } \geq 3 \text { CRS } \\
\text { was observed. } \\
\text { NEs observed in } \\
30 \% \text { of patients } \\
\text { (grade } \geq 3,10 \% \text { ) } \\
\text { at a median onset } \\
\text { of } 9 \text { days }\end{array}$ & $\begin{array}{l}{[198] /} \\
2019\end{array}$ \\
\hline DLBCL & $\begin{array}{l}\text { C19/ retroviral } \\
\text { vector } \\
\text { containing the } \\
\text { CAR } \\
\text { gene construct }\end{array}$ & Retrovirus & $\begin{array}{l}\text { anti-CD3 } \\
\text { and IL-2 }\end{array}$ & $2 \mathrm{st}$ & $\begin{array}{l}\text { The overall } \\
\text { response } \\
\text { rate was } \\
71 \%(\mathrm{n}= \\
5 / 7) \text { and } \\
\text { complete } \\
\text { response } \\
\text { (CR) rate } \\
\text { was } 57 \% \text { (n } \\
=4 / 7) \text {. }\end{array}$ & $\begin{array}{l}\text { I/II/ } \\
\text { NCT02348216 }\end{array}$ & $\begin{array}{l}\text { Grade R3 } 14 \% \\
\text { CRS and } 57 \% \\
\text { neurotoxicity was } \\
\text { observed. } \\
\text { All other KTE-C19- } \\
\text { related grade R3 } \\
\text { events were } \\
\text { resolved within } 1 \\
\text { month. }\end{array}$ & $\begin{array}{l}{[199] /} \\
2017\end{array}$ \\
\hline DLBCL & $\begin{array}{l}\mathrm{C} 19 / \text { retroviral } \\
\text { vector } \\
\text { containing the } \\
\text { CAR gene } \\
\text { construct }\end{array}$ & Retrovirus & $\begin{array}{l}\text { anti-CD3 } \\
\text { and IL-2 }\end{array}$ & $2 \mathrm{st}$ & $\begin{array}{l}\text { The } \\
\text { objective } \\
\text { response } \\
\text { rate was } \\
82 \% \text {, and the } \\
\text { complete } \\
\text { response } \\
\text { rate was } \\
54 \% \text {. } \\
\text { With a } \\
\text { median } \\
\text { follow-up of } \\
15.4 \\
\text { months, } 42 \% \\
\text { of the } \\
\text { patients } \\
\text { continued to } \\
\text { have a } \\
\text { response, } \\
\text { with } 40 \% \\
\text { continuing } \\
\text { to have a } \\
\text { complete } \\
\text { response. } \\
\text { The overall } \\
\text { rate of } \\
\text { survival at } \\
18 \text { months } \\
\text { was } 52 \% \text {. }\end{array}$ & $\begin{array}{l}\text { II/ } \\
\text { NCT02348216 }\end{array}$ & $\begin{array}{l}\text { The most } \\
\text { common adverse } \\
\text { events of grade } 3 \\
\text { or higher during } \\
\text { treatment were } \\
\text { neutropenia (in } \\
78 \% \text { of the } \\
\text { patients), anemia } \\
\text { (in } 43 \% \text { ), and } \\
\text { thrombocytopenia } \\
\text { (in } 38 \% \text { ). } \\
\text { Grade } 3 \text { or higher } \\
\text { cytokine release } \\
\text { syndrome and } \\
\text { neurologic events } \\
\text { observed in } 13 \% \\
\text { and } 28 \% \text { of the } \\
\text { patients, } \\
\text { respectively. } \\
\text { Three of the } \\
\text { patients died } \\
\text { during treatment. }\end{array}$ & $\begin{array}{l}{[200] / /} \\
2017\end{array}$ \\
\hline
\end{tabular}




\begin{tabular}{|c|c|c|c|c|c|c|c|c|}
\hline Disease & $\begin{array}{l}\text { Target } \\
\text { /Construct }\end{array}$ & $\begin{array}{l}\text { Gene delivery } \\
\text { system }\end{array}$ & Activation & $\begin{array}{l}\text { CAR } \\
\text { generation }\end{array}$ & Response & $\begin{array}{l}\text { Phase/ } \\
\text { Clinical Trials. } \\
\text { gov identifier }\end{array}$ & Toxicity & $\begin{array}{l}\text { Reference/ } \\
\text { Years }\end{array}$ \\
\hline \multirow[t]{4}{*}{ ALL } & \multirow[t]{4}{*}{$\begin{array}{l}\mathrm{C} 19 / \mathrm{CD} 3 \zeta \text { and } \\
\text { co-stimulatory } \\
\text { signals }(4-1 \mathrm{BB})\end{array}$} & \multirow[t]{4}{*}{ Lentivirus } & \multirow[t]{4}{*}{$\begin{array}{l}\text { intracellular } \\
\text { immunoreceptor } \\
\text { tyrosine-based } \\
\text { activation } \\
\text { motifs }\end{array}$} & \multirow[t]{4}{*}{$2 \mathrm{st}$} & $\begin{array}{l}83 \% \\
\text { achieved } \\
\text { CR/CRi } \\
\text { within } 3 \\
\text { months (all } \\
\text { had minimal } \\
\text { residual dis- } \\
\text { ease } \\
\text { negative } \\
\text { marrow). }\end{array}$ & \multirow[t]{4}{*}{$\begin{array}{l}\text { II/ } \\
\text { NCT02435849 }\end{array}$} & $\begin{array}{l}\text { CRS observed in } \\
78 \% \text { of patients } \\
(21 \% \text { grade } 3 ; 27 \% \\
\text { grade } 4) 49 \% \text { of } \\
\text { whom received } \\
\text { tocilizumab. } \\
\text { No deaths due to } \\
\text { refractory CRS } \\
\text { observed. }\end{array}$ & $\begin{array}{l}{[201] /} \\
2017\end{array}$ \\
\hline & & & & & \multirow[t]{3}{*}{$\begin{array}{l}\text { Relapse-free } \\
\text { probability } \\
\text { at } 6 \text { months } \\
\text { was } 75 \% \\
\text { (95\% Cl, } \\
57 \%-87 \%), \\
\text { probability } \\
\text { of 6-month } \\
\text { survival 89\% } \\
\text { (95\% Cl, } \\
77 \%-94 \%) \text {. }\end{array}$} & & $\begin{array}{l}\text { Other grades } 3 / 4 \\
\text { non-hematologic } \\
\text { AEs }(>15 \%) \text { were } \\
\text { hypotension } \\
(22 \%) \text {, and } \\
\text { hypoxia }(18 \%) \text {. } \\
15 \% \text { of patients } \\
\text { experienced grade } \\
3 \text { neurological } \\
\text { AEs, with no grade } \\
4 \text { events and no } \\
\text { cerebral edema } \\
\text { reported. }\end{array}$ & \\
\hline & & & & & & & $\begin{array}{l}60 \% \text { had grade } \\
3 / 4 \text { neutropenia } \\
\text { with high fever (> } \\
38.3 \mathrm{C}) \text {. }\end{array}$ & \\
\hline & & & & & & & $\begin{array}{l}2 \text { patients died } \\
\text { within } 30 \text { days of } \\
\text { infusion; } 9 \\
\text { patients died }>30 \\
\text { days after } \\
\text { infusion. }\end{array}$ & \\
\hline \multirow[t]{5}{*}{ DLBCL } & \multirow[t]{5}{*}{$\begin{array}{l}\mathrm{C} 19 / \mathrm{CD} 3 \zeta \text { and } \\
\text { co-stimulatory } \\
\text { signals (4-1BB) }\end{array}$} & \multirow[t]{5}{*}{ Lentivirus } & \multirow[t]{5}{*}{$\begin{array}{l}\text { intracellular } \\
\text { immunoreceptor } \\
\text { tyrosine-based } \\
\text { activation } \\
\text { motifs }\end{array}$} & \multirow[t]{5}{*}{$2 \mathrm{st}$} & \multirow[t]{5}{*}{$\begin{array}{l}95 \% \text { of CRs } \\
\text { was } \\
\text { observed in } \\
\text { at } 3 \text { months. }\end{array}$} & \multirow[t]{5}{*}{$\begin{array}{l}\text { II/ } \\
\text { NCT02445248 }\end{array}$} & $\begin{array}{l}86 \% \text { of patients } \\
\text { had grade } 3 \text { or } 4 \\
\text { AEs. } \\
\text { CRS observed in } \\
58 \% \text { of infused } \\
\text { patients, with } 15 \% \\
\text { grade } 3 \text { and } 8 \% \\
\text { grade } 4 \text {. }\end{array}$ & \multirow[t]{5}{*}{$\begin{array}{l}{[202] /} \\
2017\end{array}$} \\
\hline & & & & & & & $\begin{array}{l}\text { Other grades } 3 \text { or } \\
4 \mathrm{AEs} \text { of special } \\
\text { interest included } \\
\text { neurologic AEs } \\
(12 \% \text {, managed } \\
\text { with supportive } \\
\text { care), cytopenias } \\
\text { lasting }>28 \text { days } \\
(27 \%) \text {, infections } \\
(20 \%) \text {, and febrile } \\
\text { neutropenia } \\
(13 \%) .\end{array}$ & \\
\hline & & & & & & & $\begin{array}{l}\text { Three patients } \\
\text { died within } 30 \\
\text { days of infusion, } \\
\text { all due to disease } \\
\text { progression. }\end{array}$ & \\
\hline & & & & & & & $\begin{array}{l}\text { No deaths were } \\
\text { attributed to } \\
\text { CTL019. }\end{array}$ & \\
\hline & & & & & & & $\begin{array}{l}\text { No CRS or } \\
\text { neurologic event } \\
\text { associated deaths } \\
\text { observed. }\end{array}$ & \\
\hline
\end{tabular}




\begin{tabular}{|c|c|c|c|c|c|c|c|c|}
\hline Disease & $\begin{array}{l}\text { Target } \\
\text { /Construct }\end{array}$ & $\begin{array}{l}\text { Gene delivery } \\
\text { system }\end{array}$ & Activation & $\begin{array}{l}\text { CAR } \\
\text { generation }\end{array}$ & Response & $\begin{array}{l}\text { Phase/ } \\
\text { Clinical Trials. } \\
\text { gov identifier }\end{array}$ & Toxicity & $\begin{array}{l}\text { Reference/ } \\
\text { Years }\end{array}$ \\
\hline Lymphoma & $\begin{array}{l}\text { CD19/gamma- } \\
\text { retroviral vector } \\
\text { and contained } \\
\text { an anti-CD19 } \\
\text { single-chain } \\
\text { variable } \\
\text { fragment } \\
\text { derived from a } \\
\text { murine } \\
\text { monoclonal } \\
\text { antibody, hinge } \\
\text { and } \\
\text { transmembrane } \\
\text { regions from } \\
\text { human CD28, } \\
\text { the CD28 } \\
\text { costimulatory } \\
\text { domain, and the } \\
\text { CD3ろ T-cell } \\
\text { activation } \\
\text { domain }\end{array}$ & $\begin{array}{l}\text { Retroviral } \\
\text { vector }\end{array}$ & $\begin{array}{l}\text { the anti-CD3 } \\
\text { monoclonal } \\
\text { antibody } \\
\text { OKT3and IL-2 }\end{array}$ & $2 \mathrm{st}$ & $\begin{array}{l}\text { The overall } \\
\text { remission } \\
\text { rate was } \\
73 \% \text { with } \\
55 \% \\
\text { complete } \\
\text { remissions } \\
\text { and } 18 \% \\
\text { partial } \\
\text { remissions. }\end{array}$ & $\begin{array}{l}\text { I/II/ } \\
\text { NCT00924326 }\end{array}$ & $\begin{array}{l}\text { Fifty-five percent } \\
\text { of patients had } \\
\text { grade } 3 \text { or } 4 \\
\text { neurologic } \\
\text { toxicities that were } \\
\text { completely } \\
\text { resolved. }\end{array}$ & $\begin{array}{l}\text { [203]// } \\
2017\end{array}$ \\
\hline MCL & $\begin{array}{l}\text { CD19/retroviral } \\
\text { vector harboring } \\
\text { an anti-CD19 } \\
\text { scFv, CD3-zeta } \\
\text { T-cell activation } \\
\text { domain and } \\
\text { CD28 signaling } \\
\text { domain }\end{array}$ & $\begin{array}{l}\text { Retroviral } \\
\text { vector }\end{array}$ & $\mathrm{Nr}$ & $1 \mathrm{st}$ & $\begin{array}{l}\text { The primary } \\
\text { efficacy } \\
\text { analysis } \\
\text { showed that } \\
93 \% \text { ( } 95 \% \\
\text { confidence } \\
\text { interval [Cl], } \\
84 \text { to 98) of } \\
\text { the } 60 \\
\text { patients in } \\
\text { the primary } \\
\text { efficacy } \\
\text { analysis had } \\
\text { an objective } \\
\text { response; } \\
67 \% \text { ( } 95 \% \text { Cl, } \\
53 \text { to } 78) \\
\text { had a } \\
\text { complete } \\
\text { response. } \\
\text { In an } \\
\text { intention-to- } \\
\text { treat } \\
\text { analysis } \\
\text { involving all } \\
74 \text { patients, } \\
85 \% \text { had an } \\
\text { objective } \\
\text { response; } \\
59 \% \text { had a } \\
\text { complete } \\
\text { response. }\end{array}$ & $\begin{array}{l}\text { II/ } \\
\text { NCT02601313 }\end{array}$ & $\begin{array}{l}\text { Common adverse } \\
\text { events of grade } 3 \\
\text { or higher were } \\
\text { cytopenias (in } \\
94 \% \text { of the } \\
\text { patients) and } \\
\text { infections (in } \\
32 \% \text { ). } \\
\text { Grade } 3 \text { or higher } \\
\text { cytokine release } \\
\text { syndrome and } \\
\text { neurologic events } \\
\text { observed in } 15 \% \\
\text { and } 31 \% \text { of } \\
\text { patients, } \\
\text { respectively; none } \\
\text { were fatal. } \\
\text { Two grade } 5 \\
\text { infectious adverse } \\
\text { events observed. }\end{array}$ & $\begin{array}{l}{[204] /} \\
2020\end{array}$ \\
\hline
\end{tabular}




\begin{tabular}{|c|c|c|c|c|c|c|c|c|}
\hline Disease & $\begin{array}{l}\text { Target } \\
\text { /Construct }\end{array}$ & $\begin{array}{l}\text { Gene delivery } \\
\text { system }\end{array}$ & Activation & $\begin{array}{l}\text { CAR } \\
\text { generation }\end{array}$ & Response & $\begin{array}{l}\text { Phase/ } \\
\text { Clinical Trials. } \\
\text { gov identifier }\end{array}$ & Toxicity & $\begin{array}{l}\text { Reference/ } \\
\text { Years }\end{array}$ \\
\hline ALL & $\begin{array}{l}\text { CD19/retroviral } \\
\text { vector harboring } \\
\text { an anti-CD19 } \\
\text { scFv, CD3-zeta } \\
\text { T-cell activation } \\
\text { domain and } \\
\text { CD28 signaling } \\
\text { domain }\end{array}$ & $\begin{array}{l}\text { Retroviral } \\
\text { vector }\end{array}$ & $\mathrm{Nr}$ & $1 \mathrm{st}$ & $\begin{array}{l}\text { Among the } \\
32 \text { patients } \\
\text { evaluable } \\
\text { for response, } \\
\text { the overall } \\
\text { rate of } \\
\text { undetectable } \\
\text { MRD was } \\
78 \%(95 \% \mathrm{Cl} \text {, } \\
60-91 \%) . \\
\text { CR or CRi } \\
\text { was } \\
\text { achieved by } \\
23 \text { patients } \\
\text { (72\%), and } 1 \\
\text { patient (3\%) } \\
\text { had blast- } \\
\text { free bone } \\
\text { marrow. }\end{array}$ & I/ & $\begin{array}{l}\text { There was } 2 \text { KTE- } \\
\text { X19-related Grade } \\
5 \text { events: } 1 \\
\text { cerebral infarction } \\
\text { at the } 0.5 \times 10^{6} \\
\text { cells/kg dose and } \\
1 \text { previously } \\
\text { reported } \\
\text { multiorgan failure } \\
\text { secondary to CRS } \\
\text { at the } 2 \times 10^{6} \\
\text { cells/kg dose. } \\
\text { Grade } \geq 3 \\
\text { neurologic events } \\
\text { observed in } 16 \\
\text { patients (46\%, } \\
\text { median time to } \\
\text { onset } 7 \text { days } \\
\text { [range, } 4-24 \\
\text { days]). } \\
\text { Neurologic events } \\
\text { resolved in all } \\
\text { patients } \\
\text { (excluding } 2 \\
\text { patients with } \\
\text { unresolved events } \\
\text { at death), with a } \\
\text { median time to } \\
\text { resolution of } 17 \\
\text { days (range, } 6- \\
53 \text { days). }\end{array}$ & $\begin{array}{l}{[205] /} \\
2019\end{array}$ \\
\hline ALL & $\begin{array}{l}\text { CD19/retroviral } \\
\text { vector harboring } \\
\text { an anti-CD19 } \\
\text { scFv, CD3-zeta } \\
\text { T-cell activation } \\
\text { domain and } \\
\text { CD28 signaling } \\
\text { domain }\end{array}$ & $\begin{array}{l}\text { Retroviral } \\
\text { vector }\end{array}$ & $\mathrm{Nr}$ & $1 \mathrm{st}$ & $\begin{array}{l}\text { Of } 41 \\
\text { patients with } \\
\geq 2 \text { months } \\
\text { of follow-up, } \\
68 \% \text { had } \\
\text { CR/CRi, and } \\
73 \% \text { had } \\
\text { undetectable } \\
\text { minimal } \\
\text { residual } \\
\text { disease. } \\
\\
84 \% \text { CR/CRi, } \\
\text { was } \\
\text { observed } \\
\text { and the } \\
\text { median } \\
\text { event-free } \\
\text { survival was } \\
15 \text { months. }\end{array}$ & I/ & $\begin{array}{l}\text { The most } \\
\text { common Grade } \geq \\
3 \text { AEs were } \\
\text { hypotension } \\
\text { (38\%), pyrexia } \\
(38 \%), \text { and } \\
\text { thrombocytopenia } \\
(31 \%) \text {. } \\
\text { Grade } \geq 3 \text { CRS } \\
\text { and NEs observed } \\
\text { in } 13(29 \%) \text { and } \\
17(38 \%) \text { patients, } \\
\text { respectively. }\end{array}$ & $\begin{array}{l}{[206] /} \\
2019\end{array}$ \\
\hline ALL & $\begin{array}{l}\text { CD19/retroviral } \\
\text { vector harboring } \\
\text { an anti-CD19 } \\
\text { SCFv, CD3-zeta } \\
\text { T-cell activation } \\
\text { domain and } \\
\text { CD28 signaling } \\
\text { domain }\end{array}$ & $\begin{array}{l}\text { Retroviral } \\
\text { vector }\end{array}$ & $\mathrm{Nr}$ & $1 \mathrm{st}$ & $\begin{array}{l}\text { The CR + CRi } \\
\text { rate was } \\
100 \%, 64 \% \text {, } \\
\text { and } 71 \% \text { in } \\
\text { the } 2 \times 10^{6}, \\
1 \times 10^{6}(68- \\
\mathrm{mL}) \text {, and } 1 \times \\
10^{6}(40-\mathrm{mL}) \\
\text { groups, } \\
\text { respectively, } \\
\text { with } 25 \% \text {, } \\
71 \% \text {, and } \\
100 \% \text { of } \mathrm{CR} \\
+\mathrm{CRi} \\
\text { patients in } \\
\text { ongoing } \\
\text { response as } \\
\text { of the data } \\
\text { cutoff; and } \\
75 \%, 73 \% \text {, } \\
\text { and } 86 \% \text { of } \\
\text { all patients } \\
\text { had } \\
\text { undetectable } \\
\text { minimal } \\
\text { residual } \\
\text { disease. }\end{array}$ & I/ & $\begin{array}{l}\text { The most } \\
\text { common Grade } \geq \\
3 \text { adverse events } \\
\text { were hypotension } \\
(50 \%) \text { and anemia } \\
(33 \%) \text {. } \\
\text { Rates of Grade } \geq \\
3 \text { neurologic } \\
\text { events were } 25 \% \text {, } \\
36 \% \text {, and } 11 \% \text { in } \\
\text { the } 2 \times 10^{6}, 1 \times \\
10^{6}(68-\mathrm{mL}) \text {, and } 1 \\
\times 10^{6}(40-\mathrm{mL}) \\
\text { groups, } \\
\text { respectively, and } \\
\text { rates of Grade } \geq 3 \\
\text { cytokine release } \\
\text { syndrome were } \\
75 \%, 18 \% \text {, and } \\
22 \% \text {. } \\
\text { Overall, } 3 \text { Grade } 5 \\
\text { adverse events } \\
\text { were unrelated to } \\
\text { KTE-X19. }\end{array}$ & $\begin{array}{l}{[207] /} \\
2019\end{array}$ \\
\hline
\end{tabular}




\begin{tabular}{|c|c|c|c|c|c|c|c|c|}
\hline Disease & $\begin{array}{l}\text { Target } \\
\text { /Construct }\end{array}$ & $\begin{array}{l}\text { Gene delivery } \\
\text { system }\end{array}$ & Activation & $\begin{array}{l}\text { CAR } \\
\text { generation }\end{array}$ & Response & $\begin{array}{l}\text { Phase/ } \\
\text { Clinical Trials. } \\
\text { gov identifier }\end{array}$ & Toxicity & $\begin{array}{l}\text { Reference/ } \\
\text { Years }\end{array}$ \\
\hline DLBCL & $\begin{array}{l}\text { CD19/retroviral } \\
\text { vector harboring } \\
\text { an anti-CD19 } \\
\text { scFv, CD3-zeta } \\
\text { T-cell activation } \\
\text { domain and } \\
\text { CD28 signaling } \\
\text { domain }\end{array}$ & $\begin{array}{l}\text { Retroviral } \\
\text { vector }\end{array}$ & $\mathrm{Nr}$ & $1 \mathrm{st}$ & $\begin{array}{l}\text { Best overall } \\
\text { and } \\
\text { complete } \\
\text { response } \\
\text { rates in } \\
\text { infused } \\
\text { patients } \\
\text { were } 82 \% \\
\text { (95\% Cl, 77- } \\
86 \%) \text { and } \\
64 \%(95 \% \mathrm{Cl} \\
58-69 \%), \\
\text { respectively. } \\
\text { At a median } \\
\text { follow-up of } \\
12.9 \text { months } \\
\text { from the } \\
\text { time of CAR } \\
\text { T-cell } \\
\text { infusion, } \\
\text { median } \\
\text { progression- } \\
\text { free survival } \\
\text { was } 8.3 \\
\text { months } \\
\text { (95\% Cl, } 6.0 \\
\text { to15.1 } \\
\text { months), } \\
\text { and median } \\
\text { overall } \\
\text { survival was } \\
\text { not reached. }\end{array}$ & $\begin{array}{l}\mathrm{Nr} / \\
\text { NCT03153462 }\end{array}$ & $\begin{array}{l}\text { Among the axi- } \\
\text { cel-treated } \\
\text { patients, grade } 3 \\
\text { cytokine release } \\
\text { syndrome and } \\
\text { neurotoxicity } \\
\text { observed in } 7 \% \\
\text { and } 31 \% \text {, } \\
\text { respectively. } \\
\text { Non-relapse } \\
\text { mortality was } \\
4.4 \% \text {. }\end{array}$ & $\begin{array}{l}{[208] /} \\
2020\end{array}$ \\
\hline $\begin{array}{l}\text { B-cell } \\
\text { lymphoma } \\
\text { relapse }\end{array}$ & $\begin{array}{l}\text { CD19/retroviral } \\
\text { third-generation } \\
\text { CAR } \\
\text { Vector (RV-SFG. } \\
\text { CD19.CD28.4- } \\
\text { 1BBzeta) that } \\
\text { comprises } \\
\text { CD137 (4-1BB) } \\
\text { and CD28 as } \\
\text { costimulatory } \\
\text { domains }\end{array}$ & $\begin{array}{l}\text { Retroviral } \\
\text { vector }\end{array}$ & $\mathrm{Nr}$ & 2 st or 3 st & $\begin{array}{l}6 \text { of } 8(75 \%) \\
\text { of the } \\
\text { patients } \\
\text { responded }\end{array}$ & I/ & $\begin{array}{l}\text { CAR treatment } \\
\text { was well tolerated } \\
\text { with grade } \geq 3 \\
\text { cytokine release } \\
\text { syndrome and } \\
\text { neurotoxicity each } \\
\text { being observed } \\
\text { after } 1 \text { of } 10 \\
\text { dosings. } \\
\text { A single patient } \\
\text { had moderate } \\
\text { chronic GVHD. } \\
\text { Of note, three of } \\
\text { four patients who } \\
\text { received axi-cel } \\
\text { had ongoing } \\
\text { grade } \geq 3 \\
\text { cytopenia three } \\
\text { months post- } \\
\text { dosing, whereas } \\
\text { prolonged } \\
\text { cytopenia was not } \\
\text { observed in } 9 \\
\text { alloHCT-naïve } \\
\text { patients who } \\
\text { received axi-cel } \\
\text { during the same } \\
\text { time period. }\end{array}$ & $\begin{array}{l}{[209] /} \\
2020\end{array}$ \\
\hline
\end{tabular}

To date, the FDA has approved two CAR T cell products for non-Hodgkin lymphoma therapy, i.e., axicbtagene ciloleucel (Yescarta) and tisagenlecleucel (Kymriah) [175]. Axicabtagene ciloleucel (axi-cel) is developed for the treatment of adult patients with relapsed or refractory large B cell lymphoma, after going through at least two lines of unsuccessful systemic therapy [176]. Axi-cel is generated from bulk T cells (an undefined ratio of CD4:CD8 autologous T cells) by employing a retroviral vector that includes a CD28 costimulatory domain. Subsequent T cell activation occurs in the presence of anti-CD3 antibody and IL-2. Both the potency and the safety of axi-cel products have been evaluated in a multicenter clinical trial of over 100 adults with refractory or relapsed large B cell lymphoma. The overall response rate was $83 \%$, with $58 \%$ of the individuals achieving complete remission. At twenty-seven months of median follow-up, the progression-free survival (PFS) was 39\%. Notably, a few relapses were reported six months after axi-cel infusion. The second anti-CD19 CAR T cell product, receiving FDA approval for diffuse large B cell lymphoma (DLBCL), was tisagenleclecel (tisa-cel). Tisa-cel is generated from bulk T cells by transducing CAR T cells with a CD4-1BB costimulatory domain, using lentiviral systems [177]. The overall and complete response rates were $52 \%$ and $40 \%$, respectively. In a one year follow-up, approximately $35 \%$ of the patients indicated a progressing remission, and the overall survival of all patients undergoing tisa-cel treatment was reported to be $49 \%$. CRS was reported in $93 \%$ of the patients after axi-cel infusion, and $13 \%$ of the cases had severe CRS (grade 3-4), which occurred at a median of 2 davs after C.AR T cell infusion Tisa-cel infusion led to a $58 \%$ CRS incidence at a median of 3 days, with $11 \%$ of them identified with a severe Loading [MathJax]/jax/output/CommonHTML/jax.js

Page $18 / 32$ 
grade of CRS $[175,177]$. It is important to note that in these two studies different grading scales were applied to CRS severity. Hence, a precise comparison is impossible. It has been found, however, that both CRS and neurologic toxicity syndromes occur commonly after axi-cel infusion. It seems that the incidence and severity of toxicities in patients under axi-cel therapy may be attributed to the higher activity level of CD28 costimulatory domains in comparison to CD41BB. On the hand, the observed toxicities following CAR T cell infusions were reversible and manageable. The personalized nature of CAR T cell therapy and its undefined application protocol restricts widespread progression of CAR T cell therapies. Since it seems that several factors play a role, more thorough studies must be conducted to tackle the as yet unrsolved challenges.

\section{Future Perspectives}

CAR T cells have been introduced as a promising therapeutic modality for refractory hematologic malignancies. Additional clinical results suggest an efficient application of CAR T cells to the treatment of solid tumors. There are, however, also several obstacles, such as antigen escape, T cell dysfunction and toxicity that may occur after CAR T cell infusion. Next-generation therapeutics are being developed to overcome these barriers and to produce more efficient CAR T cells. CAR designs that target more than one antigen, sequentially or simultaneously, limit the venture of immune escape or off-tumor toxicity. Other investigations are adopting strategies to control the lifespan or activity of CAR T cells because of the deleterious effects that their long-term persistence and excessive activity may have. For solid tumors there are more hindrances in CAR T cell efficacy due to the impenetrable characteristics of the TME and its role in immune suppression. The fourth generation of CAR T cells has successfully overcome this obstacle by behaving like a living cargo and delivering immunemodulatory molecules to the TME, thereby altering the inhibitory milieu of the TME. The above mentioned limitations of CAR T cell therapy highlight the need for more in-depth investigations to broaden the applicability of CAR T cell therapy. For this purpose, several engineering strategies have recently been implemented. The increasing complexity of CAR T cell manufacturing methods, however, implicates that they are becoming more and more time-consuming and expensive. The personalized character of CAR T cell therapy additionally hampers precise comparisons between studies. Also, gene-editing, which is used for the production of CAR T cells, has increased the risk of tumor induction. Thus, supplementary studies must be conducted to enhance CAR T cell efficacy with minimal side effects and to attain a well-defined yet simplified protocol that enables production scale-up with reduced costs and risks.

\section{Conclusions}

CAR T cell therapy against B cell malignancies has exceeded expectations, leading to FDA approved CAR T cell products and several CAR T cell-based clinical trials. Due to this effective aftermath, CAR T cell therapy is considered as a promising therapeutic approach for cancer treatment. In order to optimize the efficacy of CAR T cell therapy, novel strategies have focused on rearranging and improving the structure of CAR in order to enhance its safety and specificity and decrease its on-target off-tumor toxicity. CAR T cell therapy still faces several hurdles in its application to solid tumors, including lack of tumor-restricted antigens, T cell trafficking to the tumor, immune-suppressive microenvironments and, lastly, in vivo persistence and expansion. To surmount the barriers in CAR T cell therapy for solid tumors, novel developments are aimed at structures that are: synchronically targeting several antigens, equipped by sensors that facilitate effective CAR T cell trafficking, enhanced by sensors that help distinguishing cancer cells from normal cells, and genetically modified to increase potency and resistance to immune-suppressive factors in the tumor niche. Next-generation therapeutics are poised to improve B cell therapeutics, as well as to establish these therapeutics for other malignancies, especially solid tumors.

\section{Declarations}

\section{Funding}

Not applicable

\section{Conflicts of interest/Competing interests}

The authors declare that they have no competing interests.

\section{Availability of data and material}

Not applicable

\section{Code availability}

Not applicable

\section{Authors'contributions}

MA and MM were the major contributors to the writing and revision of the manuscript. SSS and NF collected the related references and participated in discussions. MA and MM revised this article critically for important intellectual content. MS gave approval for the final version of the manuscript. All authors have read and approved the final manuscript.

\section{References}

1 A. Ribas and J.D. Wolchok, Cancer immunotherapy using checkpoint blockade. Science 359, 1350-1355 (2018)

2 S.A. Rosenberg and N.P. Restifo, Adoptive cell transfer as personalized immunotherapy for human cancer. Science 348, 62-68 (2015)

Loading [MathJax]/jax/output/CommonHTML/jax.js

Page 19/32 
L. de la Cruz-Merino, E. Grande-Pulido, A. Albero-Tamarit and M.E.C.-M. de Villena, Cancer and immune response: old and new evidence for future challenges. The Oncologist 13, 1246-1254 (2008)

4 M.E. Dudley, J.R. Wunderlich, P.F. Robbins, J.C. Yang, P. Hwu, D.J. Schwartzentruber, S.L. Topalian, R. Sherry, N.P. Restifo and A.M. Hubicki, Cancer regression and autoimmunity in patients after clonal repopulation with antitumor lymphocytes. Science 298, 850-854 (2002)

5 L. Ni and J. Lu, Interferon gamma in cancer immunotherapy. Cancer Med. 7, 4509-4516 (2018)

$6 \quad$ H.J. Jackson, S. Rafiq and R.J. Brentjens, Driving CAR T-cells forward. Nature Rev. Clin. Oncol. 13, 370 (2016)

7 G. Lipowska-Bhalla, D.E. Gilham, R.E. Hawkins and D.G. Rothwell, Targeted immunotherapy of cancer with CAR T cells: achievements and challenges. Cancer Immunol. Immunother. 61, 953-962 (2012)

C.H. June, R.S. O'Connor, O.U. Kawalekar, S. Ghassemi and M.C. Milone, CAR T cell immunotherapy for human cancer. Science 359, 1361-1365 (2018)

9 S. Srivastava and S.R. Riddell, Engineering CAR-T cells: design concepts. Trends Immunol. 36, 494-502 (2015)

10 Z.L. Chang, M.H. Lorenzini, X. Chen, U. Tran, N.J. Bangayan and Y.Y. Chen, Rewiring T-cell responses to soluble factors with chimeric antigen receptors. Nature Chem. Biol. 14, 317-324 (2018) doi: 10.1038/nchembio.2565

11 B. Savoldo, C.A. Ramos, E. Liu, M.P. Mims, M.J. Keating, G. Carrum, R.T. Kamble, C.M. Bollard, A.P. Gee and Z. Mei, CD28 costimulation improves expansion and persistence of chimeric antigen receptor-modified T cells in lymphoma patients. J. Clin. Invest. 121, 1822-1826 (2011)

12 K.S. Kahlon, C. Brown, L.J. Cooper, A. Raubitschek, S.J. Forman and M.C. Jensen, Specific recognition and killing of glioblastoma multiforme by interleukin 13-zetakine redirected cytolytic T cells. Cancer Res. 64, 9160-9166 (2004)

13 C.E. Brown, D. Alizadeh, R. Starr, L. Weng, J.R. Wagner, A. Naranjo, J.R. Ostberg, M.S. Blanchard, J. Kilpatrick and J. Simpson, Regression of glioblastoma after chimeric antigen receptor T-cell therapy. New Engl. J. Med. 375, 2561-2569 (2016)

14 T. Thayaparan, R.M. Petrovic, D.Y. Achkova, T. Zabinski, D.M. Davies, A. Klampatsa, A.C. Parente-Pereira, L.M. Whilding, S.J. van der Stegen and N. Woodman, CAR T-cell immunotherapy of MET-expressing malignant mesothelioma. Oncoimmunology 6, e1363137 (2017)

15 K. Kudo, C. Imai, P. Lorenzini, T. Kamiya, K. Kono, A.M. Davidoff, W.J. Chng and D. Campana, T lymphocytes expressing a CD16 signaling receptor exert antibody-dependent cancer cell killing. Cancer Res. 74, 93-103 (2014)

16 Y.J. Xie, M. Dougan, N. Jailkhani, J. Ingram, T. Fang, L. Kummer, N. Momin, N. Pishesha, S. Rickelt and R.O. Hynes, Nanobody-based CAR T cells that target the tumor microenvironment inhibit the growth of solid tumors in immunocompetent mice. Proc. Natl. Acad. Sci. USA 116, 7624-7631 (2019)

17 S. De Munter, J. Ingels, G. Goetgeluk, S. Bonte, M. Pille, K. Weening, T. Kerre, H. Abken and B. Vandekerckhove, Nanobody based dual specific CARs. Int. J. Mol. Sci. 19, 403 (2018)

18 P. Bannas, J. Hambach and F. Koch-Nolte, Nanobodies and nanobody-based human heavy chain antibodies as antitumor therapeutics. Front. Immunol. 8, 1603 (2017)

19 C.E. Brown and P.S. Adusumilli, Next frontiers in CAR T-cell therapy. Mol. Therapy-Oncolytics 3, 16028 (2016)

20 C.A. Ramos and G. Dotti, Chimeric antigen receptor (CAR)-engineered lymphocytes for cancer therapy. Exp. Opin. Biol. Ther. 11, 855-873 (2011)

21 Z. Zhao, M. Condomines, S.J.C. van der Stegen, F. Perna, C.C. Kloss, G. Gunset, J. Plotkin and M. Sadelain, Structural design of engineered costimulation determines tumor rejection kinetics and persistence of CAR T cells. Cancer Cell 28, 415-428 (2015) doi: 10.1016/j.ccell.2015.09.004

220. U. Kawalekar, R.S. O'Connor, J.A. Fraietta, L. Guo, S.E. McGettigan, A.D. Posey Jr, P.R. Patel, S. Guedan, J. Scholler and B. Keith, Distinct signaling of coreceptors regulates specific metabolism pathways and impacts memory development in CAR T cells. Immunity 44, 380-390 (2016)

23 S.J. Van Der Stegen, M. Hamieh and M. Sadelain, The pharmacology of second-generation chimeric antigen receptors. Nature Rev. Drug Disc. 14, 499$509(2015)$

24 A.H. Long, W.M. Haso, J.F. Shern, K.M. Wanhainen, M. Murgai, M. Ingaramo, J.P. Smith, A.J. Walker, M.E. Kohler and V.R. Venkateshwara, 4-1BB costimulation ameliorates T cell exhaustion induced by tonic signaling of chimeric antigen receptors. Nature Med. 21, 581 (2015)

25 C.J. Turtle and D.G. Maloney, Clinical trials of CD19-targeted CAR-modified T cell therapy; a complex and varied landscape. Exp. Rev. Hematol. 9, 719721 (2016) doi: 10.1080/17474086.2016.1203251

26 A.E. Foster, A. Mahendravada, N.P. Shinners, W.-C. Chang, J. Crisostomo, A. Lu, M. Khalil, E. Morschl, J.L. Shaw and S. Saha, Regulated expansion and survival of chimeric antigen receptor-modified T cells using small molecule-dependent inducible MyD88/CD40. Mol. Ther. 25, 2176-2188 (2017)

27 M. Mata, C. Gerken, P. Nguyen, G. Krenciute, D.M. Spencer and S. Gottschalk, Inducible activation of MyD88 and CD40 in CAR T cells results in

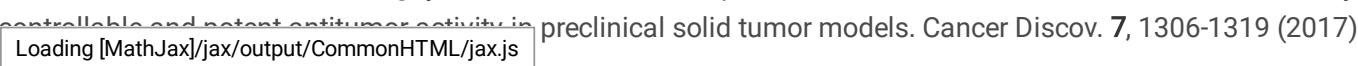

Page $20 / 32$ 

human T cells in vivo. Blood 119, 696-706 (2012)

29 M.A. Pulè, K.C. Straathof, G. Dotti, H.E. Heslop, C.M. Rooney and M.K. Brenner, A chimeric T cell antigen receptor that augments cytokine release and supports clonal expansion of primary human T cells. Mol. Ther. 12, 933-941 (2005)

30 A.A. Hombach, J. Heiders, M. Foppe, M. Chmielewski and H. Abken, OX40 costimulation by a chimeric antigen receptor abrogates CD28 and IL-2 induced IL-10 secretion by redirected CD4+ T cells. Oncoimmunology 1, 458-466 (2012)

31 H.M. Finney, A.N. Akbar and A.D. Lawson, Activation of resting human primary T cells with chimeric receptors: costimulation from CD28, inducible costimulator, CD134, and CD137 in series with signals from the TCR弓 chain. J. Immunol. 172, 104-113 (2004)

32 S. Guedan, X. Chen, A. Madar, C. Carpenito, S.E. McGettigan, M.J. Frigault, J. Lee, A.D. Posey, J. Scholler and N. Scholler, ICOS-based chimeric antigen receptors program bipolar TH17/TH1 cells. Blood 124, 1070-1080 (2014)

33 E. Wang, L.C. Wang, C.Y. Tsai, V. Bhoj, Z. Gershenson, E. Moon, K. Newick, J. Sun, A. Lo, T. Baradet, M.D. Feldman, D. Barrett, E. Pure, S. Albelda and M.C. Milone, Generation of potent T-cell immunotherapy for cancer using DAP12-based, multichain, chimeric immunoreceptors. Cancer Immunol. Res. 3, 815826 (2015) doi: 10.1158/2326-6066.CIR-15-0054

34 S. Rafiq, C.S. Hackett and R.J. Brentjens, Engineering strategies to overcome the current roadblocks in CAR T cell therapy. Nature Rev. Clin. Oncol. 17, 147-167 (2020) doi: 10.1038/s41571-019-0297-y

35 J.S. Bridgeman, R.E. Hawkins, S. Bagley, M. Blaylock, M. Holland and D.E. Gilham, The optimal antigen response of chimeric antigen receptors harboring the CD3zeta transmembrane domain is dependent upon incorporation of the receptor into the endogenous TCR/CD3 complex .J. Immunol. 184, 6938-6949 (2010) doi: 10.4049/jimmunol.0901766

D. Abate-Daga and M.L. Davila, CAR models: next-generation CAR modifications for enhanced T-cell function. Mol. Ther. Oncolyt. 3, 16014 (2016)

37 G. Dotti, S. Gottschalk, B. Savoldo and M.K. Brenner, Design and development of therapies using chimeric antigen receptor-expressing T cells. Immunol. Rev. 257, 107-126 (2014)

38 S.E. James, P.D. Greenberg, M.C. Jensen, Y. Lin, J. Wang, B.G. Till, A.A. Raubitschek, S.J. Forman and O.W. Press, Antigen sensitivity of CD22-specific chimeric TCR is modulated by target epitope distance from the cell membrane. J. Immunol. 180, 7028-7038 (2008)

39 W. Haso, D.W. Lee, N.N. Shah, M. Stetler-Stevenson, C.M. Yuan, I.H. Pastan, D.S. Dimitrov, R.A. Morgan, D.J. FitzGerald and D.M. Barrett, Anti-CD22chimeric antigen receptors targeting B-cell precursor acute lymphoblastic leukemia. Blood 121, 1165-1174 (2013)

40 R.D. Guest, R.E. Hawkins, N. Kirillova, E.J. Cheadle, J. Arnold, A. O'Neill, J. Irlam, K.A. Chester, J.T. Kemshead and D.M. Shaw, The role of extracellular spacer regions in the optimal design of chimeric immune receptors: evaluation of four different scFvs and antigens. J. Immunother. 28, 203-211 (2005)

41 M.H. Kershaw, J.A. Westwood, L.L. Parker, G. Wang, Z. Eshhar, S.A. Mavroukakis, D.E. White, J.R. Wunderlich, S. Canevari and L. Rogers-Freezer, A phase I study on adoptive immunotherapy using gene-modified T cells for ovarian cancer. Clin. Cancer Res. 12, 6106-6115 (2006)

42 M.C. Jensen, L. Popplewell, L.J. Cooper, D. DiGiusto, M. Kalos, J.R. Ostberg and S.J. Forman, Antitransgene rejection responses contribute to attenuated persistence of adoptively transferred CD20/CD19-specific chimeric antigen receptor redirected T cells in humans. Biol. Blood Marrow Transpl. 16, 1245-1256 (2010)

43 S.L. Maude, N. Frey, P.A. Shaw, R. Aplenc, D.M. Barrett, N.J. Bunin, A. Chew, V.E. Gonzalez, Z. Zheng and S.F. Lacey, Chimeric antigen receptor T cells for sustained remissions in leukemia. New Engl. J. Med. 371, 1507-1517 (2014)

44 R.J. Brentjens, M.L. Davila, I. Riviere, J. Park, X. Wang, L.G. Cowell, S. Bartido, J. Stefanski, C. Taylor and M. Olszewska, CD19-targeted T cells rapidly induce molecular remissions in adults with chemotherapy-refractory acute lymphoblastic leukemia. Science Transl. Med. 5, 177ra138-177ra138 (2013)

45 J.N. Kochenderfer, W.H. Wilson, J.E. Janik, M.E. Dudley, M. Stetler-Stevenson, S.A. Feldman, I. Maric, M. Raffeld, D.-A.N. Nathan and B.J. Lanier, Eradication of B-lineage cells and regression of lymphoma in a patient treated with autologous T cells genetically engineered to recognize CD19. Blood 116, 4099-4102 (2010)

46 M. Chmielewski, C. Kopecky, A.A. Hombach and H. Abken, IL-12 release by engineered T cells expressing chimeric antigen receptors can effectively Muster an antigen-independent macrophage response on tumor cells that have shut down tumor antigen expression. Cancer Res. 71, 5697-5706 (2011)

47 M.L. Schubert, J.M. Hoffmann, P. Dreger, C. Müller-Tidow and M. Schmitt, Chimeric antigen receptor transduced T cells: tuning up for the next generation. Int. J. Cancer 142, 1738-1747 (2018)

48 P. Chang, Interleukin 12-secreting chimeric antigen receptor T cells and cancer immunotherapy. 1-110 (2016)

49 B. Hu, J. Ren, Y. Luo, B. Keith, R.M. Young, J. Scholler, Y. Zhao and C.H. June, Augmentation of antitumor immunity by human and mouse CAR T cells

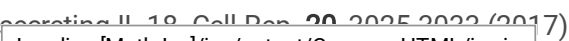

Loading [MathJax]/jax/output/CommonHTML/jax.js

Page $21 / 32$ 
G. Gross and Z. Eshhar, Therapeutic potential of T cell chimeric antigen receptors (CARs) in cancer treatment: Counteracting off-tumor toxicities for safe CAR T cell therapy. Ann. Rev. Pharmacol. Toxicol. 56, 59-83 (2016) doi: 10.1146/annurev-pharmtox-010814-124844

51 T. Giavridis, S.J. van der Stegen, J. Eyquem, M. Hamieh and M. Sadelain, CAR T cell-induced cytokine release syndrome is mediated by macrophages and abated by IL-1 blockade. Nature Med. 24, 731-738 (2018)

52 J. Gust, A. Taraseviciute and C.J. Turtle, Neurotoxicity associated with CD19-targeted CAR-T cell therapies. CNS Drugs 32, 1091-1101 (2018)

53 M. Namuduri and R.J. Brentjens, Medical management of side effects related to CAR T cell therapy in hematologic malignancies. Exp. Rev. Hematol. 9, 511-513 (2016)

54 K. Minagawa and A. Di Stasi, Novel toxicology challenges in the era of chimeric antigen receptor T-cells therapies. Transl. Cancer Res. 1-6 (2016)

55 D.W. Lee, B.D. Santomasso, F.L. Locke, A. Ghobadi, C.J. Turtle, J.N. Brudno, M.V. Maus, J.H. Park, E. Mead, S. Pavletic, W.Y. Go, L. Eldjerou, R.A. Gardner, N. Frey, K.J. Curran, K. Peggs, M. Pasquini, J.F. DiPersio, M.R.M. van den Brink, K.V. Komanduri, S.A. Grupp and S.S. Neelapu, ASTCT Consensus grading for cytokine release syndrome and neurologic toxicity associated with immune effector cells. Biol. Blood Marrow Transpl. 25, 625-638 (2019) doi: 10.1016/j.bbmt.2018.12.758

56 K.M. Mahadeo, S.J. Khazal, H. Abdel-Azim, J.C. Fitzgerald, A. Taraseviciute, C.M. Bollard, P. Tewari, C. Duncan, C. Traube, D. McCall, M.E. Steiner, I.M. Cheifetz, L.E. Lehmann, R. Mejia, J.M. Slopis, R. Bajwa, P. Kebriaei, P.L. Martin, J. Moffet, J. McArthur, D. Petropoulos, J. O'Hanlon Curry, S. Featherston, J. Foglesong, B. Shoberu, A. Gulbis, M.E. Mireles, L. Hafemeister, C. Nguyen, N. Kapoor, K. Rezvani, S.S. Neelapu, E.J. Shpall, I. Pediatric acute lung and N. sepsis investigators, management guidelines for paediatric patients receiving chimeric antigen receptor T cell therapy. Nature Rev. Clin. Oncol. 16, 45-63 (2019) doi: $10.1038 /$ s41571-018-0075-2

57 T. Giavridis, S.J.C. van der Stegen, J. Eyquem, M. Hamieh, A. Piersigilli and M. Sadelain, CAR T cell-induced cytokine release syndrome is mediated by macrophages and abated by IL-1 blockade. Nature Med. 24, 731-738 (2018) doi: 10.1038/s41591-018-0041-7

58 D.W. Lee, R. Gardner, D.L. Porter, C.U. Louis, N. Ahmed, M. Jensen, S.A. Grupp and C.L. Mackall, Current concepts in the diagnosis and management of cytokine release syndrome. Blood 124, 188-195 (2014)

59 M. Sachdeva, P. Duchateau, S. Depil, L. Poirot and J. Valton, Granulocyte-macrophage colony-stimulating factor inactivation in CAR T-cells prevents monocyte-dependent release of key cytokine release syndrome mediators. J. Biol. Chem. 294, 5430-5437 (2019)

60 J. Gust, K.A. Hay, L.-A. Hanafi, D. Li, D. Myerson, L.F. Gonzalez-Cuyar, C. Yeung, W.C. Liles, M. Wurfel and J.A. Lopez, Endothelial activation and bloodbrain barrier disruption in neurotoxicity after adoptive immunotherapy with CD19 CAR-T cells. Cancer Discov. 7, 1404-1419 (2017)

61 C.K. Chou and C.J. Turtle, Insight into mechanisms associated with cytokine release syndrome and neurotoxicity after CD19 CAR-T cell immunotherapy. Bone Marrow Transpl. 54, 780-784 (2019) doi: 10.1038/s41409-019-0602-5

62 C. Perrinjaquet, N. Desbaillets and A.F. Hottinger, Neurotoxicity associated with cancer immunotherapy: immune checkpoint inhibitors and chimeric antigen receptor T-cell therapy. Curr. Opin. Neurol. 32, 500-510 (2019)

63 U.H. Acharya, T. Dhawale, S. Yun, C.A. Jacobson, J.C. Chavez, J.D. Ramos, J. Appelbaum and D.G. Maloney, Management of cytokine release syndrome and neurotoxicity in chimeric antigen receptor (CAR) T cell therapy. Expert Rev. Hematol. 12, 195-205 (2019)

64 H.J. Jackson and R.J. Brentjens, Overcoming antigen escape with CAR T-cell therapy. Cancer Discov. 5, 1238-1240 (2015)

65 E. Sotillo, D.M. Barrett, K.L. Black, A. Bagashev, D. Oldridge, G. Wu, R. Sussman, C. Lanauze, M. Ruella and M.R. Gazzara, Convergence of acquired mutations and alternative splicing of CD19 enables resistance to CART-19 immunotherapy. Cancer Discov. 5, 1282-1295 (2015)

66 F. Braig, A. Brandt, M. Goebeler, H.-P. Tony, A.-K. Kurze, P. Nollau, T. Bumm, S. Böttcher, R.C. Bargou and M. Binder, Resistance to anti-CD19/CD3 BiTE in acute lymphoblastic leukemia may be mediated by disrupted CD19 membrane trafficking. Blood 129, 100-104 (2017)

67 S. Rafiq and R.J. Brentjens, Tumors evading CARs-the chase is on. Nature Med. 24, 1492-1493 (2018)

68 J. Fischer, C. Paret, K. El Malki, F. Alt, A. Wingerter, M.A. Neu, B. Kron, A. Russo, N. Lehmann and L. Roth, CD19 isoforms enabling resistance to CART19 immunotherapy are expressed in B-ALL patients at initial diagnosis. J. Immunother. 40, 187 (2017)

69 R. Gardner, D. Wu, S. Cherian, M. Fang, L.-A. Hanafi, O. Finney, H. Smithers, M.C. Jensen, S.R. Riddell and D.G. Maloney, Acquisition of a CD19-negative myeloid phenotype allows immune escape of MLL-rearranged B-ALL from CD19 CAR-T-cell therapy. Blood 127, 2406-2410 (2016)

70 E.J. Orlando, X. Han, C. Tribouley, P.A. Wood, R.J. Leary, M. Riester, J.E. Levine, M. Qayed, S.A. Grupp and M. Boyer, Genetic mechanisms of target antigen loss in CAR19 therapy of acute lymphoblastic leukemia. Nature Med. 24, 1504-1506 (2018)

71 B. Heyman and Y. Yang, Chimeric antigen receptor T cell therapy for solid tumors: current status, obstacles and future strategies. Cancers 11, 191 (2019) 
73 I. Diaconu, B. Ballard, M. Zhang, Y. Chen, J. West, G. Dotti and B. Savoldo, Inducible caspase-9 selectively modulates the toxicities of CD19-specific chimeric antigen receptor-modified T cells. Mol. Ther. 25, 580-592 (2017)

74 A. Di Stasi, S.-K. Tey, G. Dotti, Y. Fujita, A. Kennedy-Nasser, C. Martinez, K. Straathof, E. Liu, A.G. Durett and B. Grilley, Inducible apoptosis as a safety switch for adoptive cell therapy. New Engl. J. Med. 365, 1673-1683 (2011)

75 R. Sakemura, S. Terakura, K. Watanabe, J. Julamanee, E. Takagi, K. Miyao, D. Koyama, T. Goto, R. Hanajiri and T. Nishida, A Tet-On inducible system for controlling CD19-chimeric antigen receptor expression upon drug administration. Cancer Immunol. Res. 4, 658-668 (2016)

76 C.-Y. Wu, K.T. Roybal, E.M. Puchner, J. Onuffer and W.A. Lim, Remote control of therapeutic T cells through a small molecule-gated chimeric receptor. Science 350, aab4077 (2015)

77 J.H. Cho, J.J. Collins and W.W. Wong, Universal chimeric antigen receptors for multiplexed and logical control of T cell responses. Cell 173, 14261438. e1411 (2018)

78 J. Zhao, Q. Lin, Y. Song and D. Liu, Universal CARs, universal T cells, and universal CAR T cells. J. Hematol. Oncol. 11, 132 (2018)

79 K.T. Roybal, L.J. Rupp, L. Morsut, W.J. Walker, K.A. McNally, J.S. Park and W.A. Lim, Precision tumor recognition by T cells with combinatorial antigensensing circuits. Cell. 164, 770-779 (2016)

80 M. Themeli and M. Sadelain, Combinatorial antigen targeting: ideal T-cell sensing and anti-tumor response. Trends Mol. Med. 22, 271-273 (2016)

81 S. Srivastava, A.I. Salter, D. Liggitt, S. Yechan-Gunja, M. Sarvothama, K. Cooper, K.S. Smythe, J.A. Dudakov, R.H. Pierce and C. Rader, Logic-gated ROR1 chimeric antigen receptor expression rescues T cell-mediated toxicity to normal tissues and enables selective tumor targeting. Cancer Cell 35, $489-503$. e488 (2019)

82 S. Wilkie, M.C. van Schalkwyk, S. Hobbs, D.M. Davies, S.J. van der Stegen, A.C.P. Pereira, S.E. Burbridge, C. Box, S.A. Eccles and J. Maher, Dual targeting of ErbB2 and MUC1 in breast cancer using chimeric antigen receptors engineered to provide complementary signaling. J. Clin. Immunol. 32, 10591070 (2012)

83 C.C. Kloss, M. Condomines, M. Cartellieri, M. Bachmann and M. Sadelain, Combinatorial antigen recognition with balanced signaling promotes selective tumor eradication by engineered T cells. Nature Biotechnol. 31, 71 (2013)

84 D. Xu, G. Jin, D. Chai, X. Zhou, W. Gu, Y. Chong, J. Song and J. Zheng, The development of CAR design for tumor CAR-T cell therapy. Oncotarget 9 , $13991(2018)$

85 M. Hegde, M. Mukherjee, Z. Grada, A. Pignata, D. Landi, S.A. Navai, A. Wakefield, K. Fousek, K. Bielamowicz and K.K. Chow, Tandem CAR T cells targeting HER2 and IL13Ra2 mitigate tumor antigen escape. J. Clin. Invest. 126, 3036-3052 (2016)

86 M.A. Rosenthal, C. Balana, M.E. van Linde, C. Sayehli, W.M. Fiedler, M. Wermke, C. Massard, I.K. Mellinghoff, M. Khasraw and A. Ang, ATIM-49 (LTBK01). AMG 596, a novel anti-EGFRvIll bispecific T cell engager (BiTE®) molecule for the treatment of glioblastoma (GBM): planned interim analysis in recurrent GBM (rGBM). Neuro-Oncology 21, vi283 (2019)

87 D.M. O'Rourke, M.P. Nasrallah, A. Desai, J.J. Melenhorst, K. Mansfield, J.J. Morrissette, M. Martinez-Lage, S. Brem, E. Maloney and A. Shen, A single dose of peripherally infused EGFRvIll-directed CAR T cells mediates antigen loss and induces adaptive resistance in patients with recurrent glioblastoma. Science Transl. Med. 9, 399 (2017)

88 D.M. O'Rourke, M. Nasrallah, J.J. Morrissette, J.J. Melenhorst, S.F. Lacey, K. Mansfield, M. Martinez-Lage, A.S. Desai, S. Brem and E. Maloney, Pilot study of T cells redirected to EGFRvIll with a chimeric antigen receptor in patients with EGFRvIll+ glioblastoma. J. Clin. Oncol. 2067-2067 (2016)

89 M. Chen, R. Sun, B. Shi, Y. Wang, S. Di, H. Luo, Y. Sun, Z. Li, M. Zhou and H. Jiang, Antitumor efficacy of chimeric antigen receptor T cells against EGFRvIll-expressing glioblastoma in C57BL/6 mice. Biomed.Pharmacother. 113, 108734 (2019)

90 M. Ruella and B.L. Levine, Smart CARS: optimized development of a chimeric antigen receptor (CAR) T cell targeting epidermal growth factor receptor variant III (EGFRvIII) for glioblastoma. Ann. Transl. Med. 4, 13 (2016)

91 H.G. Caruso, A.B. Heimberger and L.J. Cooper, Steering CAR T cells to distinguish friend from foe. Oncoimmunol. 8, e1271857 (2019)

92 V.D. Fedorov, M. Themeli and M. Sadelain, PD-1-and CTLA-4-based inhibitory chimeric antigen receptors (iCARs) divert off-target immunotherapy responses. Science Transl. Med. 5, 215ra172-215ra172 (2013)

93 V.D. Fedorov, M. Sadelain and C.C. Kloss, Novel approaches to enhance the specificity and safety of engineered T cells. The Cancer Journal 20, $160-$ 165 (2014)

Loading [MathJax]/jax/output/CommonHTML/jax.js 

expressing advanced relapsed/refractory non-small cell lung cancer. Science China Life Sciences 59, 468-479 (2016)

95 E. Drent, M. Themeli, R. Poels, R. de Jong-Korlaar, H. Yuan, J. de Bruijn, A.C. Martens, S. Zweegman, N.W. van de Donk and R.W. Groen, A rational strategy for reducing on-target off-tumor effects of CD38-chimeric antigen receptors by affinity optimization. Mol. Ther. 25, 1946-1958 (2017)

96 Y. Liu, X. Chen, W. Han and Y. Zhang, Tisagenlecleucel, an approved anti-CD19 chimeric antigen receptor T-cell therapy for the treatment of leukemia. Drugs Today 53, 597-608 (2017)

97 A.L. Garfall, M.V. Maus, W.-T. Hwang, S.F. Lacey, Y.D. Mahnke, J.J. Melenhorst, Z. Zheng, D.T. Vogl, A.D. Cohen and B.M. Weiss, Chimeric antigen receptor T cells against CD19 for multiple myeloma. New Engl. J. Med. 373, 1040-1047 (2015)

98 S.A. Grupp, M. Kalos, D. Barrett, R. Aplenc, D.L. Porter, S.R. Rheingold, D.T. Teachey, A. Chew, B. Hauck and J.F. Wright, Chimeric antigen receptormodified T cells for acute lymphoid leukemia. New Engl. J. Med. 368, 1509-1518 (2013)

99 D.W. Lee, J.N. Kochenderfer, M. Stetler-Stevenson, Y.K. Cui, C. Delbrook, S.A. Feldman, T.J. Fry, R. Orentas, M. Sabatino and N.N. Shah, T cells expressing CD19 chimeric antigen receptors for acute lymphoblastic leukaemia in children and young adults: a phase 1 dose-escalation trial. The Lancet $\mathbf{3 8 5}$, $517-528(2015)$

100 E. Zhang, J. Gu and H. Xu, Prospects for chimeric antigen receptor-modified T cell therapy for solid tumors. Mol. Cancer 17, 7 (2018)

101 A. Holzinger and H. Abken, CAR T cells targeting solid tumors: carcinoembryonic antigen (CEA) proves to be a safe target. Cancer Immunol. Immunother. 66, 1505-1507 (2017)

102 P. Bocca, E. Di Carlo, I. Caruana, L. Emionite, M. Cilli, B. De Angelis, C. Quintarelli, A. Pezzolo, L. Raffaghello and F. Morandi, Bevacizumab-mediated tumor vasculature remodelling improves tumor infiltration and antitumor efficacy of GD2-CAR T cells in a human neuroblastoma preclinical model. Oncoimmunology 7, e1378843 (2018)

103 A. Morello, M. Sadelain and P.S. Adusumilli,Mesothelin-targeted CARs: driving T cells to solid tumors. Cancer Discov. 6, 133-146 (2016)

104 H. Abken, Driving CARs on the highway to solid cancer: some considerations on the adoptive therapy with CAR T cells. Human Gene Ther. 28, 10471060 (2017)

105 N. Ahmed, V.S. Brawley, M. Hegde, C. Robertson, A. Ghazi, C. Gerken, E. Liu, O. Dakhova, A. Ashoori and A. Corder, Human epidermal growth factor receptor 2 (HER2)-specific chimeric antigen receptor-modified T cells for the immunotherapy of HER2-positive sarcoma. J. Cin. Oncol. 33, 1688 (2015)

106 E. Lanitis, M. Irving and G. Coukos, Targeting the tumor vasculature to enhance T cell activity. Curr.Opin. Immunol. 33, 55-63 (2015)

107 A. Schmidts and M.V. Maus, Making CAR T cells a solid option for solid tumors. Frontiers Immunol. 9, 2593 (2018)

108 U. Sahin, E. Derhovanessian, M. Miller, B.-P. Kloke, P. Simon, M. Löwer, V. Bukur, A.D. Tadmor, U. Luxemburger and B. Schrörs, Personalized RNA mutanome vaccines mobilize poly-specific therapeutic immunity against cancer. Nature 547, 222-226 (2017)

109 P.A. Ott, Z. Hu, D.B. Keskin, S.A. Shukla, J. Sun, D.J. Bozym, W. Zhang, A. Luoma, A. Giobbie-Hurder and L. Peter, An immunogenic personal neoantigen vaccine for patients with melanoma. Nature 547, 217-221 (2017)

110 S. Stevanović, A. Pasetto, S.R. Helman, J.J. Gartner, T.D. Prickett, B. Howie, H.S. Robins, P.F. Robbins, C.A. Klebanoff and S.A. Rosenberg, Landscape of immunogenic tumor antigens in successful immunotherapy of virally induced epithelial cancer. Science 356, 200-205 (2017)

111 J. Zhou, M.E. Dudley, S.A. Rosenberg and P.F. Robbins, Persistence of multiple tumor-specific T-cell clones is associated with complete tumor regression in a melanoma patient receiving adoptive cell transfer therapy. J. Immunother. 28, 53 (2005)

112 K.C. Pituch, J. Miska, G. Krenciute, W.K. Panek, G. Li, T. Rodriguez-Cruz, M. Wu, Y. Han, M.S. Lesniak and S. Gottschalk, Adoptive transfer of IL13Ra2specific chimeric antigen receptor T cells creates a pro-inflammatory environment in glioblastoma. Mol. Ther. 26, 986-995 (2018)

113 K. Bielamowicz, K. Fousek, T.T. Byrd, H. Samaha, M. Mukherjee, N. Aware, M.-F. Wu, J.S. Orange, P. Sumazin and T.-K. Man, Trivalent CAR T cells overcome interpatient antigenic variability in glioblastoma. Neuro-Oncology 20, 506-518 (2018)

114 S. Van Schandevyl and T. Kerre, Chimeric antigen receptor T-cell therapy: design improvements and therapeutic strategies in cancer treatment. Acta Clinica Belgica 75, 26-32 (2020)

115 A.K. Park, S. Priceman, E. Gerdts, W.-C. Chang, S. Wright, S.J. Forman and C.E. Brown, Development of chimeric antigen receptor (CAR) T-cell immunotherapy for glioblastoma targeting epidermal growth factor receptor variant III (EGFRvIII). J. Immunother. Cancer 3, P119 (2015)

116 A. Sahin, C. Sanchez, S. Bullain, P. Waterman, R. Weissleder and B.S. Carter, Development of third generation anti-EGFRvIll chimeric T cells and EGFRvIll-expressing artificial antigen presenting cells for adoptive cell therapy for glioma. PloS One 13, e0199414 (2018)

Loading [MathJax]/jax/output/CommonHTML/jax.js rget selection for CAR-T therapy. J. Hematol. Oncol. 12, 1-9 (2019) 
118 G. Xie, N.A. Ivica, B. Jia, Y. Li, H. Dong, Y. Liang, D. Brown, R. Rizwan and J. Chen, Author Correction: CAR-T cells targeting a nucleophosmin neoepitope exhibit potent specific activity in mouse models of acute myeloid leukaemia. Nature Biomedical Engineering 5, 124 (2021)

119 I. Scarfò and M.V. Maus, Current approaches to increase CAR T cell potency in solid tumors: targeting the tumor microenvironment. J. Immunother. Cancer 5, 1-8 (2017)

120 B. Liu, L. Yan and M. Zhou,Target selection of CAR T cell therapy in accordance with the TME for solid tumors.Am. J. Cancer Res. 9, 228 (2019)

121 A. Lo, L.-C.S. Wang, J. Scholler, J. Monslow, D. Avery, K. Newick, S. O'Brien, R.A. Evans, D.J. Bajor and C. Clendenin, Tumor-promoting desmoplasia is disrupted by depleting FAP-expressing stromal cells. Cancer Res. 75, 2800-2810 (2015)

122 L.-C.S. Wang, A. Lo, J. Scholler, J. Sun, R.S. Majumdar, V. Kapoor, M. Antzis, C.E. Cotner, L.A. Johnson and A.C. Durham, Targeting fibroblast activation protein in tumor stroma with chimeric antigen receptor T cells can inhibit tumor growth and augment host immunity without severe toxicity. Cancer Immunol. Res. 2, 154-166 (2014)

123 R. Sackstein, T. Schatton and S.R. Barthel, T-lymphocyte homing: an underappreciated yet critical hurdle for successful cancer immunotherapy. Lab. Invest. 97, 669 (2017)

124 E.K. Moon, C. Carpenito, J. Sun, L.-C.S. Wang, V. Kapoor, J. Predina, D.J. Powell, J.L. Riley, C.H. June and S.M. Albelda, Expression of a functional CCR2 receptor enhances tumor localization and tumor eradication by retargeted human T cells expressing a mesothelin-specific chimeric antibody receptor. Clin. Cancer Res. 17, 4719-4730 (2011)

125 J.A. Craddock, A. Lu, A. Bear, M. Pule, M.K. Brenner, C.M. Rooney and A.E. Foster, Enhanced tumor trafficking of GD2 chimeric antigen receptor T cells by expression of the chemokine receptor CCR2b. J. Immunother. $\mathbf{3 3}, 780$ (2010)

126 A. Di Stasi, B. De Angelis, C.M. Rooney, L. Zhang, A. Mahendravada, A.E. Foster, H.E. Heslop, M.K. Brenner, G. Dotti and B. Savoldo, T lymphocytes coexpressing CCR4 and a chimeric antigen receptor targeting CD30 have improved homing and antitumor activity in a Hodgkin tumor model. Blood 113, 63926402 (2009)

127 I. Siddiqui, M. Erreni, M. Van Brakel, R. Debets and P. Allavena, Enhanced recruitment of genetically modified CX3CR1-positive human T cells into Fractalkine/CX3CL1 expressing tumors: importance of the chemokine gradient. J. Immunother. Cancer 4, 21 (2016)

128 W. Peng, Y. Ye, B.A. Rabinovich, C. Liu, Y. Lou, M. Zhang, M. Whittington, Y. Yang, W.W. Overwijk and G. Lizée, Transduction of tumor-specific T cells with CXCR2 chemokine receptor improves migration to tumor and antitumor immune responses. Clin. Cancer Res. 16, 5458-5468 (2010)

129 P. Spear, A. Barber and C.L. Sentman, Collaboration of chimeric antigen receptor (CAR)-expressing T cells and host T cells for optimal elimination of established ovarian tumors. Oncoimmunology 2, e23564 (2013)

130 N. Tokarew, J. Ogonek, S. Endres, M. von Bergwelt-Baildon and S. Kobold, Teaching an old dog new tricks: next-generation CAR T cells. Brit. J. Cancer 120, 26-37 (2019) doi: 10.1038/s41416-018-0325-1

131 M.M. D'Aloia, I.G. Zizzari, B. Sacchetti, L. Pierelli and M. Alimandi, CAR-T cells: the long and winding road to solid tumors. Cell Death Dis. 9, 282 (2018) doi: 10.1038/s41419-018-0278-6

132 N. Kanagawa, M. Niwa, Y. Hatanaka, Y. Tani, S. Nakagawa, T. Fujita, A. Yamamoto and N. Okada, CC-chemokine ligand 17 gene therapy induces tumor regression through augmentation of tumor-infiltrating immune cells in a murine model of preexisting CT26 colon carcinoma. Int. J. Cancer 121, $2013-2022$ (2007) doi: 10.1002/ijc.22908

133 E. Lavergne, C. Combadiere, M. Iga, A. Boissonnas, O. Bonduelle, M. Maho, P. Debre and B. Combadiere, Intratumoral CC chemokine ligand 5 overexpression delays tumor growth and increases tumor cell infiltration. J. Immunol. 173, 3755-3762 (2004) doi: 10.4049/jimmunol.173.6.3755

134 S.J. Priceman, D. Tilakawardane, B. Jeang, B. Aguilar, J.P. Murad, A.K. Park, W.-C. Chang, J.R. Ostberg, J. Neman and R. Jandial, Regional delivery of chimeric antigen receptor-engineered T cells effectively targets HER2+ breast Cancer metastasis to the brain. Clin. Cancer Res. 24, 95-105 (2018)

135 A. Louveau, T.H. Harris and J. Kipnis, Revisiting the mechanisms of CNS immune privilege. Trends Immunol. 36, 569-577 (2015)

136 B.D. Choi, C.M. Suryadevara, P.C. Gedeon, J.E. Herndon II, L. Sanchez-Perez, D.D. Bigner and J.H. Sampson, Intracerebral delivery of a third generation EGFRvIll-specific chimeric antigen receptor is efficacious against human glioma. J. Clin. Neurosci. 21, 189-190 (2014)

137 C.E. Brown, D. Alizadeh, R. Starr, L. Weng, J.R. Wagner, A. Naranjo, J.R. Ostberg, M.S. Blanchard, J. Kilpatrick, J. Simpson, A. Kurien, S.J. Priceman, X. Wang, T.L. Harshbarger, M. D'Apuzzo, J.A. Ressler, M.C. Jensen, M.E. Barish, M. Chen, J. Portnow, S.J. Forman and B. Badie, Regression of glioblastoma after chimeric antigen receptor T-cell therapy. New Engl. J. Med. 375, 2561-2569 (2016) doi: 10.1056/NEJMoa1610497

138 J. Tchou, Y. Zhao, B.L. Levine, P.J. Zhang, M.M. Davis, J.J. Melenhorst, I. Kulikovskaya, A.L. Brennan, X. Liu, S.F. Lacey, A.D. Posey, Jr., A.D. Williams, A. So, J.R. Conejo-Garcia, G. Plesa, R.M. Young, S. McGettigan, J. Campbell, R.H. Pierce, J.M. Matro, A.M. DeMichele, A.S. Clark, L.J. Cooper, L.M. Schuchter, R.H. Vonderheide and C.H. June, Safety and efficacy of intratumoral injections of chimeric antigen receptor (CAR) T cells in metastatic breast cancer. Cancer Loading [MathJax]/jax/output/CommonHTML/jax.js 158/2326-6066.CIR-17-0189

Page 25/32 
139 S.C. Katz, R.A. Burga, E. McCormack, L.J. Wang, W. Mooring, G.R. Point, P.D. Khare, M. Thorn, Q. Ma, B.F. Stainken, E.O. Assanah, R. Davies, N.J. Espat and R.P. Junghans, Phase I hepatic immunotherapy for metastases study of intra-arterial chimeric antigen receptor-modified T-cell therapy for CEA+ liver metastases. Clin. Cancer Res. 21, 3149-3159 (2015) doi: 10.1158/1078-0432.CCR-14-1421

140 D.H. Yoon, M.J. Osborn, J. Tolar and C.J. Kim, Incorporation of immune checkpoint blockade into chimeric antigen receptor T cells (CAR-Ts): Combination or built-in CAR-T. Int. J. Mol. Sci. 19, 340 (2018) doi: 10.3390/ijms19020340

141 B.T. Aftab, R.R. Shen, C.D. Pham, M. Wu, D.J. Munson, P.S. Adusumilli, M. Zauderer, V. Rusch, R. O'Cearbhaill and A. Zhu, A Phase I clinical trial of malignant pleural disease treated with regionally delivered autologous mesothelin-targeted CAR T cells: Safety and efficacy. (2019)

142 I. Caruana, B. Savoldo, V. Hoyos, G. Weber, H. Liu, E.S. Kim, M.M. Ittmann, D. Marchetti and G. Dotti, Heparanase promotes tumor infiltration and antitumor activity of CAR-redirected T lymphocytes. Nature Med. 21, 524 (2015)

143 M. Binnewies, E.W. Roberts, K. Kersten, V. Chan, D.F. Fearon, M. Merad, L.M. Coussens, D.I. Gabrilovich, S. Ostrand-Rosenberg and C.C. Hedrick, Understanding the tumor immune microenvironment (TIME) for effective therapy. Nature Med. 24, 541-550 (2018)

144 M. Overchuk and G. Zheng, Overcoming obstacles in the tumor microenvironment: Recent advancements in nanoparticle delivery for cancer theranostics. Biomaterials 156, 217-237 (2018)

145 A.H. Long, S.L. Highfill, Y. Cui, J.P. Smith, A.J. Walker, S. Ramakrishna, R. El-Etriby, S. Galli, M.G. Tsokos and R.J. Orentas, Reduction of MDSCs with alltrans retinoic acid improves CAR therapy efficacy for sarcomas. Cancer Immunol. Res. 4, 869-880 (2016)

146 V. Kumar, S. Patel, E. Tcyganov and D.I. Gabrilovich, The nature of myeloid-derived suppressor cells in the tumor microenvironment. Trends Immunol. 37, 208-220 (2016)

147 D.H. Yoon, M.J. Osborn, J. Tolar and C.J. Kim, Incorporation of immune checkpoint blockade into chimeric antigen receptor T cells (CAR-Ts): combination or built-in CAR-T. Int. J. Mol. Sci. 19, 340 (2018)

148 L.J. Rupp, K. Schumann, K.T. Roybal, R.E. Gate, J.Y. Chun, W.A. Lim and A. Marson, CRISPR/Cas9-mediated PD-1 disruption enhances anti-tumor efficacy of human chimeric antigen receptor T cells. Sci. Rep. 7, 1-10 (2017)

149 J. Ren, X. Zhang, X. Liu, C. Fang, S. Jiang, C.H. June and Y. Zhao, A versatile system for rapid multiplex genome-edited CAR T cell generation. Oncotarget 8, $17002(2017)$

150 Y. Zhang, X. Zhang, C. Cheng, W. Mu, X. Liu, N. Li, X. Wei, X. Liu, C. Xia and H. Wang, CRISPR-Cas9 mediated LAG-3 disruption in CAR-T cells. Front. Med. 11, 554-562 (2017)

151 S. Rafiq, O.O. Yeku, H.J. Jackson, T.J. Purdon, D.G. van Leeuwen, D.J. Drakes, M. Song, M.M. Miele, Z. Li and P. Wang, Targeted delivery of a PD-1blocking scFv by CAR-T cells enhances anti-tumor efficacy in vivo. Nature Biotechnol. 36, 847-856 (2018)

152 X. Liu, R. Ranganathan, S. Jiang, C. Fang, J. Sun, S. Kim, K. Newick, A. Lo, C.H. June and Y. Zhao, A chimeric switch-receptor targeting PD1 augments the efficacy of second-generation CAR T cells in advanced solid tumors. Cancer Res. 76, 1578-1590 (2016)

153 A.M. Leen, S. Sukumaran, N. Watanabe, S. Mohammed, J. Keirnan, R. Yanagisawa, U. Anurathapan, D. Rendon, H.E. Heslop and C.M. Rooney, Reversal of tumor immune inhibition using a chimeric cytokine receptor. Molecular Therapy 22, 1211-1220 (2014)

154 K. Adachi, Y. Kano, T. Nagai, N. Okuyama, Y. Sakoda and K. Tamada, IL-7 and CCL19 expression in CAR-T cells improves immune cell infiltration and CAR-T cell survival in the tumor. Nature Biotechnol. 36, 346 (2018)

155 C.S. Hinrichs, R. Spolski, C.M. Paulos, L. Gattinoni, K.W. Kerstann, D.C. Palmer, C.A. Klebanoff, S.A. Rosenberg, W.J. Leonard and N.P. Restifo, IL-2 and IL-21 confer opposing differentiation programs to CD8+ T cells for adoptive immunotherapy. Blood 111, 5326-5333 (2008)

156 M. Koneru, T.J. Purdon, D. Spriggs, S. Koneru and R.J. Brentjens, IL-12 secreting tumor-targeted chimeric antigen receptor T cells eradicate ovarian tumors in vivo. Oncoimmunology 4, e994446 (2015)

157 O.O. Yeku, T.J. Purdon, M. Koneru, D. Spriggs and R.J. Brentjens, Armored CAR T cells enhance antitumor efficacy and overcome the tumor microenvironment. Sci. Rep. 7, 1-14 (2017)

158 M. Koneru, R. O'Cearbhaill, S. Pendharkar, D.R. Spriggs and R.J. Brentjens, A phase I clinical trial of adoptive T cell therapy using IL-12 secreting MUC16 ecto directed chimeric antigen receptors for recurrent ovarian cancer. J. Transl. Med. 13, 102 (2015)

159 M. Chmielewski and H. Abken, CAR T cells releasing IL-18 convert to T-Bethigh Fox01low effectors that exhibit augmented activity against advanced solid tumors. Cell Rep. 21, 3205-3219 (2017)

160 M.C. Schmid, C.J. Avraamides, H.C. Dippold, I. Franco, P. Foubert, L.G. Ellies, L.M. Acevedo, J.R. Manglicmot, X. Song and W. Wrasidlo, Receptor tyrosine kinases and TLR/IL1Rs unexpectedly activate myeloid cell PI3ky, a single convergent point promoting tumor inflammation and progression. Cancer fall $10715707(2011)$

Loading [MathJax]/jax/output/CommonHTML/jax.js

Page 26/32 
162 M.L. Davila, I. Riviere, X. Wang, S. Bartido, J. Park, K. Curran, S.S. Chung, J. Stefanski, O. Borquez-Ojeda and M. Olszewska, Efficacy and toxicity management of 19-28z CAR T cell therapy in B cell acute lymphoblastic leukemia. Sci. Transl. Med. 6, 224ra225-224ra225 (2014)

163 D. Sommermeyer, M. Hudecek, P.L. Kosasih, T. Gogishvili, D.G. Maloney, C.J. Turtle and S.R. Riddell, Chimeric antigen receptor-modified T cells derived from defined CD8+ and CD4+ subsets confer superior antitumor reactivity in vivo. Leukemia 30, 492-500 (2016)

164 C. Berger, M.C. Jensen, P.M. Lansdorp, M. Gough, C. Elliott and S.R. Riddell, Adoptive transfer of effector CD8+ T cells derived from central memory cells establishes persistent T cell memory in primates. J. Clin. Invest. 118, 294-305 (2008)

165 X. Wang and I. Rivière, Clinical manufacturing of CAR T cells: foundation of a promising therapy. Mol. Therapy-Oncolytics 3, 16015 (2016)

166 M.C. Jensen, P. Clarke, G. Tan, C. Wright, W. Chung-Chang, T.N. Clark, F. Zhang, M.L. Slovak, A.M. Wu and S.J. Forman, Human T lymphocyte genetic modification with naked DNA. Mol. Ther. 1, 49-55 (2000)

167 S. Ghassemi, F. Bedoya, S. Nunez-Cruz, C. June, J. Melenhorst and M. Milone, Shortened T cell culture with IL-7 and IL-15 provides the most potent chimeric antigen receptor (CAR)-modified T cells for adoptive immunotherapy. J. Immunol. 196, 214-223 (2016)

168 J.N. Kochenderfer, S.A. Feldman, Y. Zhao, H. Xu, M.A. Black, R.A. Morgan, W.H. Wilson and S.A. Rosenberg, Construction and pre-clinical evaluation of an anti-CD19 chimeric antigen receptor. J. Immunother. 32, 689 (2009

169 H. Singh, J. Moyes, M. Huls and L. Cooper, Manufacture of T cells using the Sleeping Beauty system to enforce expression of a CD19-specific chimeric antigen receptor. Cancer Gene Ther. 22, 95-100 ( (2015

170 P. Kebriaei, H. Huls, H. Singh, S. Olivares, M. Figliola, S. Maiti, S. Shihuang, P.R. Kumar, B. Jena and M.A. Forget, Adoptive therapy using sleeping beauty gene transfer system and artificial antigen presenting cells to manufacture T cells expressing CD19-specific chimeric antigen receptor. Blood 124, 311$311(2014)$

171 M. Kalos, B.L. Levine, D.L. Porter, S. Katz, S.A. Grupp, A. Bagg and C.H. June, T cells with chimeric antigen receptors have potent antitumor effects and can establish memory in patients with advanced leukemia. Sci. Transl. Med. 3, 95ra73-95ra73 (2011)

172 B.L. Levine, J. Miskin, K. Wonnacott and C. Keir,Global manufacturing of CAR T cell therapy.Mol. Ther. Meth. Clin. Dev. 4, 92-101 (2017)

173 S. Ramanayake, I. Bilmon, D. Bishop, M.-C. Dubosq, E. Blyth, L. Clancy, D. Gottlieb and K. Micklethwaite, Low-cost generation of Good Manufacturing Practice-grade CD19-specific chimeric antigen receptor-expressing T cells using piggyBac gene transfer and patient-derived materials. Cytotherapy 17, 12511267 (2015)

174 G.L. Beatty, A.R. Haas, M.V. Maus, D.A. Torigian, M.C. Soulen, G. Plesa, A. Chew, Y. Zhao, B.L. Levine and S.M. Albelda, Mesothelin-specific chimeric antigen receptor mRNA-engineered T cells induce antitumor activity in solid malignancies. Cancer Immunol Res. 2, 112-120 (2014)

175 P.-P. Zheng, J.M. Kros and J. Li, Approved CAR T cell therapies: ice bucket challenges on glaring safety risks and long-term impacts. Drug Discov. Today 23, 1175-1182 (2018)

176 L.J. Nastoupil, M.D. Jain, J.Y. Spiegel, A. Ghobadi, Y. Lin, S. Dahiya, M.A. Lunning, L.J. Lekakis, P.M. Reagan and O.O. Oluwole, Axicabtagene ciloleucel (axi-cel) CD19 chimeric antigen receptor (CAR) T-cell therapy for relapsed/refractory large B-cell lymphoma: real world experience. Blood 132, 91-91 (2018)

177 V. Prasad, Tisagenlecleucel-the first approved CAR-T-cell therapy: implications for payers and policy makers. Nature Rev. Clin. Oncol. 15, 11-12 (2018)

178 J.R. Park, D.L. DiGiusto, M. Slovak, C. Wright, A. Naranjo, J. Wagner, H.B. Meechoovet, C. Bautista, W.-C. Chang and J.R. Ostberg, Adoptive transfer of chimeric antigen receptor re-directed cytolytic T lymphocyte clones in patients with neuroblastoma. Mol. Ther. 15, 825-833 (2007)

179 C.U. Louis, B. Savoldo, G. Dotti, M. Pule, E. Yvon, G.D. Myers, C. Rossig, H.V. Russell, O. Diouf and E. Liu, Antitumor activity and long-term fate of chimeric antigen receptor-positive T cells in patients with neuroblastoma. Blood 118, 6050-6056 (2011)

180 C.E. Brown, B. Badie, M.E. Barish, L. Weng, J.R. Ostberg, W.-C. Chang, A. Naranjo, R. Starr, J. Wagner and C.J.C.c.r. Wright, Bioactivity and safety of IL13Ra2-redirected chimeric antigen receptor CD8+ T cells in patients with recurrent glioblastoma. Clin. Cancer Res. 21, 4062-4072 (2015)

181 C.E. Brown, D. Alizadeh, R. Starr, L. Weng, J.R. Wagner, A. Naranjo, J.R. Ostberg, M.S. Blanchard, J. Kilpatrick and J.J.N.E.J.o.M. Simpson, Regression of glioblastoma after chimeric antigen receptor T-cell therapy. New Engl. J. Med. 375, 2561-2569 (2016)

182 R.P. Junghans, Q. Ma, R. Rathore, E.M. Gomes, A.J. Bais, A.S. Lo, M. Abedi, R.A. Davies, H.J. Cabral and A.S.J.T.P. Al-Homsi, Phase I trial of anti-PSMA designer CAR-T cells in prostate cancer: possible role for interacting interleukin 2-T cell pharmacodynamics as a determinant of clinical response. The Prostate 76,1257-1270 (2016)

183 R.A. Morgan, J.C. Yang, M. Kitano, M.E. Dudley, C.M. Laurencot and S.A.J.M.T. Rosenberg, Case report of a serious adverse event following the administration of T cells transduced with a chimeric antigen receptor recognizing ERBB2. Mol. Ther. 18, $843-851$ (2010)

Loading [MathJax]/jax/output/CommonHTML/jax.js

Page $27 / 32$ 
184 F.C. Thistlethwaite, D.E. Gilham, R.D. Guest, D.G. Rothwell, M. Pillai, D.J. Burt, A.J. Byatte, N. Kirillova, J.W. Valle and S.K.J.C.I. Sharma, The clinical efficacy of first-generation carcinoembryonic antigen (CEACAM5)-specific CAR T cells is limited by poor persistence and transient pre-conditioning-dependent respiratory toxicity. Cancer Immunol. 66, 1425-1436 (2017)

185 C.H. Lamers, S. Sleijfer, S. Van Steenbergen, P. Van Elzakker, B. Van Krimpen, C. Groot, A. Vulto, M. Den Bakker, E. Oosterwijk and R.J.M.t. Debets, Treatment of metastatic renal cell carcinoma with CAIX CAR-engineered T cells: clinical evaluation and management of on-target toxicity. Mol. Ther. 21, 904$912(2013)$

186 E. Van Cutsem, J. Machiels, M. Van den Eynde, H. Prenen, A. Hendlisz, L. Shaza, J. Carrasco, J. Canon, P. Sotiropoulou and E.J.A.o.O. Breman, Phase 1 studies assessing the safety and clinical activity of autologous and allogeneic NKG2D-based CAR-T therapy in metastatic colorectal cancer. Ann. Oncol. 30, iv124-iv125 (2019)

187 G.L. Beatty, M.H. O’Hara, S.F. Lacey, D.A. Torigian, F. Nazimuddin, F. Chen, I.M. Kulikovskaya, M.C. Soulen, M. McGarvey and A.M.J.G. Nelson, Activity of mesothelin-specific chimeric antigen receptor T cells against pancreatic carcinoma metastases in a phase 1 trial. Gastroenterology 155, 29-32 (2018)

188 D.M. O’Rourke, M.P. Nasrallah, A. Desai, J.J. Melenhorst, K. Mansfield, J.J. Morrissette, M. Martinez-Lage, S. Brem, E. Maloney and A.J.S.t.m. Shen, A single dose of peripherally infused EGFRvIII-directed CAR T cells mediates antigen loss and induces adaptive resistance in patients with recurrent glioblastoma. Sci. Transl. Med. 9, eaaa0984 (2017)

189 M. Koneru, R. O'Cearbhaill, S. Pendharkar, D.R. Spriggs and R.J.J.J.o.t.m. Brentjens, A phase I clinical trial of adoptive T cell therapy using IL-12 secreting MUC-16 ecto directed chimeric antigen receptors for recurrent ovarian cancer. J. Transl. Med. 13, 102 (2015)

190 S.L. Goff, R.A. Morgan, J.C. Yang, R.M. Sherry, P.F. Robbins, N.P. Restifo, S.A. Feldman, Y.-C. Lu, L. Lu and Z.J.J.o.I. Zheng, Pilot trial of adoptive transfer of chimeric antigen receptor-transduced T cells targeting EGFRvIll in patients with glioblastoma. J. Immunother. 42, 126-135 (2019)

191 N. Ahmed, V. Brawley, M. Hegde, K. Bielamowicz, M. Kalra, D. Landi, C. Robertson, T.L. Gray, O. Diouf and A.J.J.o. Wakefield, Her2-specific chimeric antigen receptor-modified virus-specific t cells for progressive glioblastoma: a phase 1 dose-escalation trial. JAMA Oncology 3, 1094-1101 (2017)

192 J. Tchou, Y. Zhao, B.L. Levine, P.J. Zhang, M.M. Davis, J.J. Melenhorst, I. Kulikovskaya, A.L. Brennan, X. Liu and S.F.J.C.i.r. Lacey, Safety and efficacy of intratumoral injections of chimeric antigen receptor (CAR) T cells in metastatic breast cancer. Cancer Immunol. Res. 5, 1152-1161 (2017)

193 P.S. Adusumilli, M.G. Zauderer, V.W. Rusch, R. O'Cearbhaill, A. Zhu, D. Ngai, E. McGee, N. Chintala, J. Messinger and W. Cheema, Regional delivery of mesothelin-targeted CAR T cells for pleural cancers: Safety and preliminary efficacy in combination with anti-PD-1 agent. J. Clin. Oncol. 37, 2511-2511 (2019)

194 C. Zhang, Z. Wang, Z. Yang, M. Wang, S. Li, Y. Li, R. Zhang, Z. Xiong, Z. Wei and J. Shen, Phase I escalating-dose trial of CAR-T therapy targeting CEA+ metastatic colorectal cancers. Mol. Ther. 25, 1248-1258 (2017)

195 B.G. Till, M.C. Jensen, J. Wang, E.Y. Chen, B.L. Wood, H.A. Greisman, X. Qian, S.E. James, A. Raubitschek and S.J.J.B. Forman, Adoptive immunotherapy for indolent non-Hodgkin lymphoma and mantle cell lymphoma using genetically modified autologous CD20-specific T cells. J. Am. Soc. Hematol. 112, 2261-2271 (2008)

196 Q.-s. Wang, Y. Wang, H.-y. Lv, Q.-w. Han, H. Fan, B. Guo, L.-I. Wang and W.-d.J.M.t. Han, Treatment of CD33-directed chimeric antigen receptor-modified T cells in one patient with relapsed and refractory acute myeloid leukemia. Mol. Ther. 23, 184-191 (2015)

197 J.S. Abramson, L. Palomba, L.I. Gordon, M. Lunning, J. Arnason, A. Forero-Torres, T.M. Albertson, V.S. Exton, C. Sutherland and B. Xie, Transcend NHL 001: immunotherapy with the CD19-directed CAR T-cell product JCAR017 results in high complete response rates in relapsed or refractory B-cell non-Hodgkin lymphoma. Blood 128, 4192-4192 (2016)

198 J.S. Abramson, M.L. Palomba, L.I. Gordon, M.A. Lunning, M.L. Wang, J.E. Arnason, A. Mehta, E. Purev, D.G. Maloney and C. Andreadis, Pivotal safety and efficacy results from Transcend NHL 001, a multicenter phase 1 study of lisocabtagene maraleucel (liso-cel) in relapsed/refractory (R/R) large B cell lymphomas. Blood 134, 241- 241 (2019)

199 F.L. Locke, S.S. Neelapu, N.L. Bartlett, T. Siddiqi, J.C. Chavez, C.M. Hosing, A. Ghobadi, L.E. Budde, A. Bot and J.M.J.M.T. Rossi, Phase 1 results of ZUMA-1: a multicenter study of KTE-C19 anti-CD19 CAR T cell therapy in refractory aggressive lymphoma. Mol. Ther. 25, 285-295 (2017)

200 S.S. Neelapu, F.L. Locke, N.L. Bartlett, L.J. Lekakis, D.B. Miklos, C.A. Jacobson, I. Braunschweig, O.O. Oluwole, T. Siddiqi and Y.J.N.E.J.o.M. Lin, Axicabtagene ciloleucel CAR T-cell therapy in refractory large B-cell lymphoma. New Engl. J. Med. 377, 2531-2544 (2017)

201 J. Buechner, S.A. Grupp, S.L. Maude, M. Boyer, H. Bittencourt, T.W. Laetsch, P. Bader, M.R. Verneris, H. Stefanski, G.D.J.C.L. Myers, Myeloma and leukemia, global registration trial of efficacy and safety of CTL019 in pediatric and young adult patients with relapsed/refractory (R/R) acute lymphoblastic leukemia (ALL): update to the interim analysis. Clin. Lymph. Myel. Leukemia 17, S263-S264 (2017)

202 S.J. Schuster, M.R. Bishop, C.S. Tam, E.K. Waller, P. Borchmann, J.P. McGuirk, U. Jaeger, S. Jaglowski, C. Andreadis and J.R.J.B. Westin, Primary analysis of Juliet: a global, pivotal, phase 2 trial of CTL019 in adult patients with relapsed or refractory diffuse large B-cell lymphoma. Blood 130, 577-577 (2017)

Loading [MathJax]/jax/output/CommonHTML/jax.js 
203 J.N. Kochenderfer, R.P. Somerville, T. Lu, V. Shi, A. Bot, J. Rossi, A. Xue, S.L. Goff, J.C. Yang and R.M.J.J.o.C.O. Sherry, Lymphoma remissions caused by anti-CD19 chimeric antigen receptor T cells are associated with high serum interleukin-15 levels. J. Clin. Oncol. 35, 1803 (2017)

204 M. Wang, J. Munoz, A. Goy, F.L. Locke, C.A. Jacobson, B.T. Hill, J.M. Timmerman, H. Holmes, S. Jaglowski and I.W. Flinn, KTE-X19 CAR T-cell therapy in relapsed or refractory mantle-cell lymphoma. New Engl. J. Med. 382, 1331-1342 (2020)

205 W.G. Wierda, M.R. Bishop, O. Oluwole, A.C. Logan, M.R. Baer, W.B. Donnellan, K.M. O'Dwyer, J.E. Castro, G.J. Schiller, H.J.B.o.B. Holmes and M, Updated phase 1 results of Zuma-3: Kte-X19, an anti-CD19 chimeric a antigen receptorT Cell therapy, in adult patients with relapsed/refractory acute lymphoblastic leukemia. Transplantation 25, S185 (2019)

206 B. Shah, M. Bishop, O. Oluwole, A. Logan, M. Baer, W. Donnellan, K. O'Dwyer, H. Holmes, M. Arellano and A.J.H. Ghobadi, KTE-X19, AN ANTI-CD19 CHIMERIC ANTIGEN RECEPTOR T CELL THERAPY, IN ADULT PATIENTS WITH RELAPSED/REFRACTORY ACUTE LYMPHOBLASTIC LEUKEMIA: END OF PHASE 1 RESULTS OF ZUMA-3. HemaSphere 3, 426 (2019)

207 A. Wayne, V. Huynh, N. Hijiya, R. Rouce, P. Brown, J. Krueger, M. Rytting, C. Kitko, E.D. Ziga and M.J.H. Hermiston, PHASE 1 RESULTS OF ZUMA-4: KTEX19, AN ANTI-CD19 CHIMERIC ANTIGEN RECEPTOR T CELL THERAPY, IN PEDIATRIC AND ADOLESCENT PATIENTS WITH RELAPSED/REFRACTORY B CELL ACUTE LYMPHOBLASTIC LEUKEMIA. HemaSphere 3, 433 (2019)

208 L.J. Nastoupil, M.D. Jain, L. Feng, J.Y. Spiegel, A. Ghobadi, Y. Lin, S. Dahiya, M. Lunning, L. Lekakis and P.J.J.o.C.O. Reagan, Standard-of-care axicabtagene ciloleucel for relapsed or refractory large B-cell lymphoma: Results from the US lymphoma CAR T consortium. J. Clin. Oncol. 19, 3119-3128 (2020)

209 M.-L. Schuber, S. Dietrich, S. Stilgenbauer, A. Schmitt, P. Pavel, A. Kunz, A. Bondong, M. Wegner, P. Stadtherr, S.J.B.o.B. Jung and M, Feasibility and safety of CD19 CAR T cell treatment for B-cell lymphoma relapse after allogeneic hematopoietic stem cell transplantation. Biol. Blood Bone Marrow Transpl . 26, 1575-1580 (2020)

\section{Figures}

A

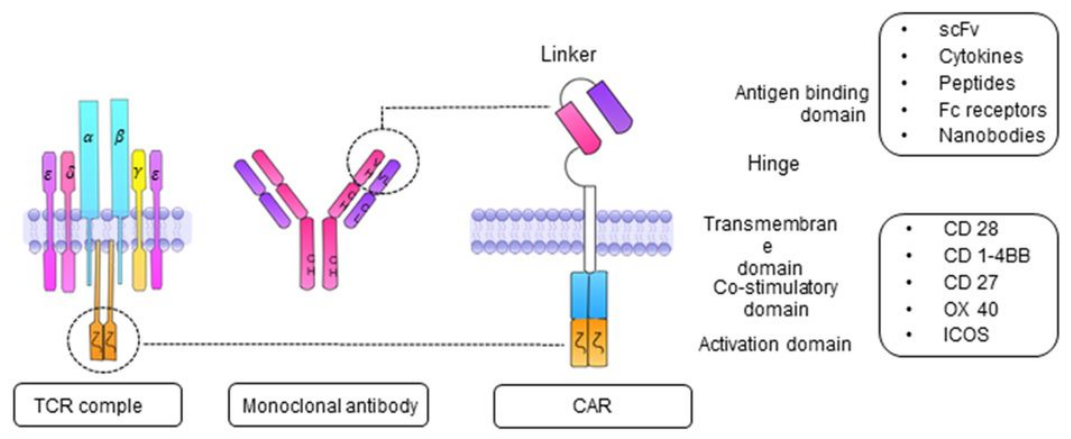

B

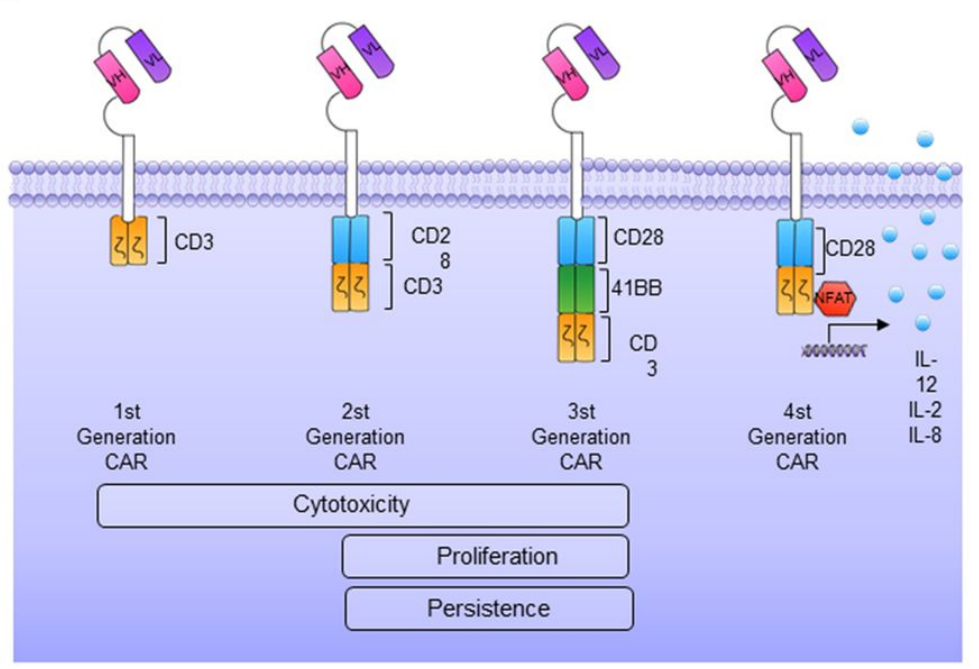


CAR structure and generation. A. CAR molecules have a modular structure with segments derived from monoclonal antibodies and the TCR complex. CAR molecules comprise an antigen-binding domain, a hinge, a transmembrane domain and an intracellular signaling domain including activation and costimulatory domains. In CAR T cell studies, various domains have been used within each of the segments. The antigen-binding domain and the co-stimulatory domain have been manipulated more than other segments and more variations are observed in these segments; B. CAR T cells can be categorized into 4 generations, based on the CAR structures and domains implemented in their designs.
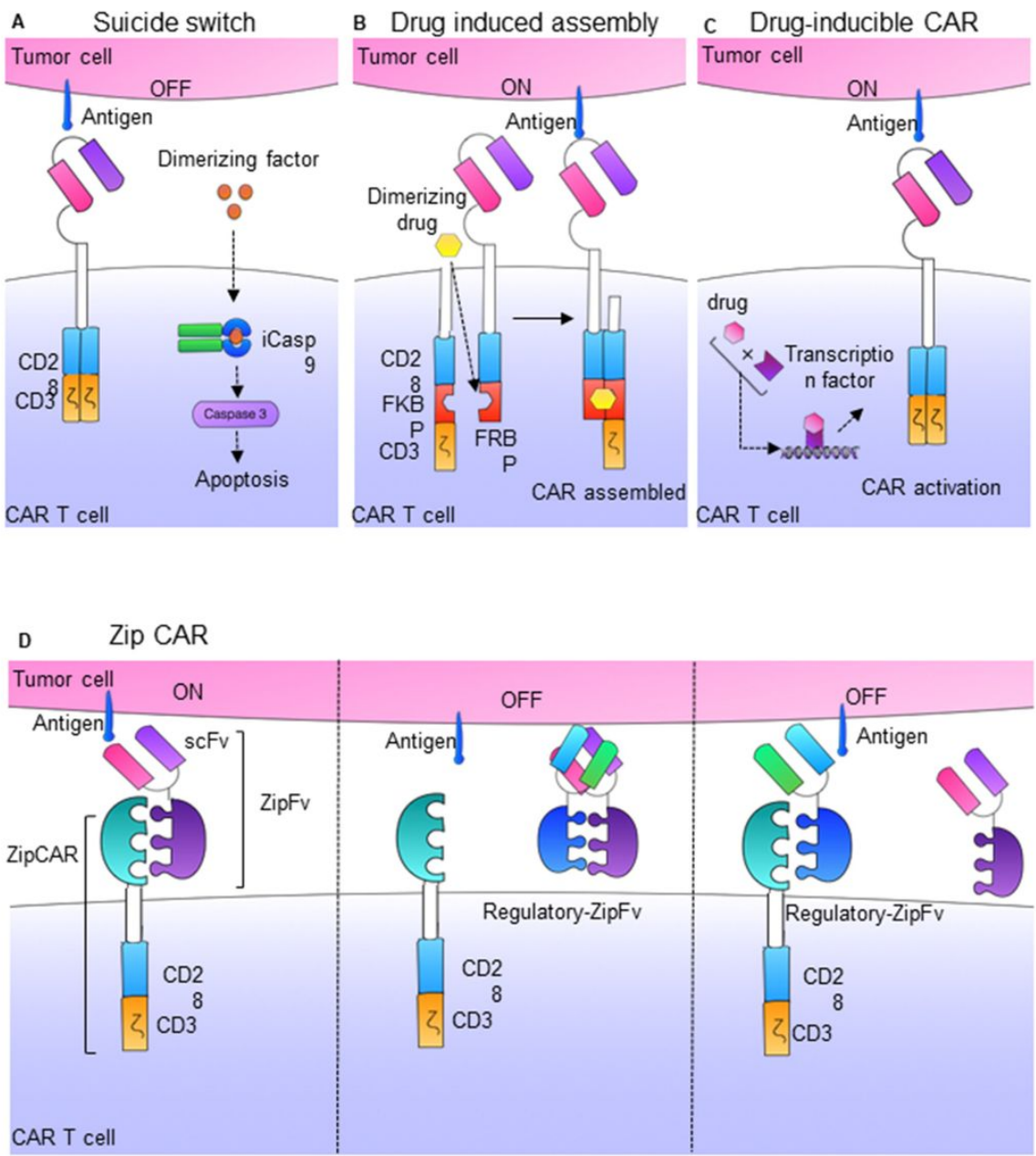

\section{Figure 2}

Management of CAR T cell activation strategies. A. The suicide-gene approach provides the possibility to eliminate CAR T cells by induction of apoptosis via iCaspase-signaling activation; B. Adding a small-molecule adapter ligand allows the assembly of two moieties of non-functional CARs and the creation of functional CAR T cells; C. CAR expression occurs through the induction of chemical agents; D. Based on the Zip CAR approach, the CAR consists of two moieties. Zip CAR and Zip fv moieties with matched segments are attached together and form a functional CAR T cell. The Zip CAR T cell activity is inhibited by the external regulatory Zip fv with complementary structures to the original Zip fv and Zip CAR. 
A

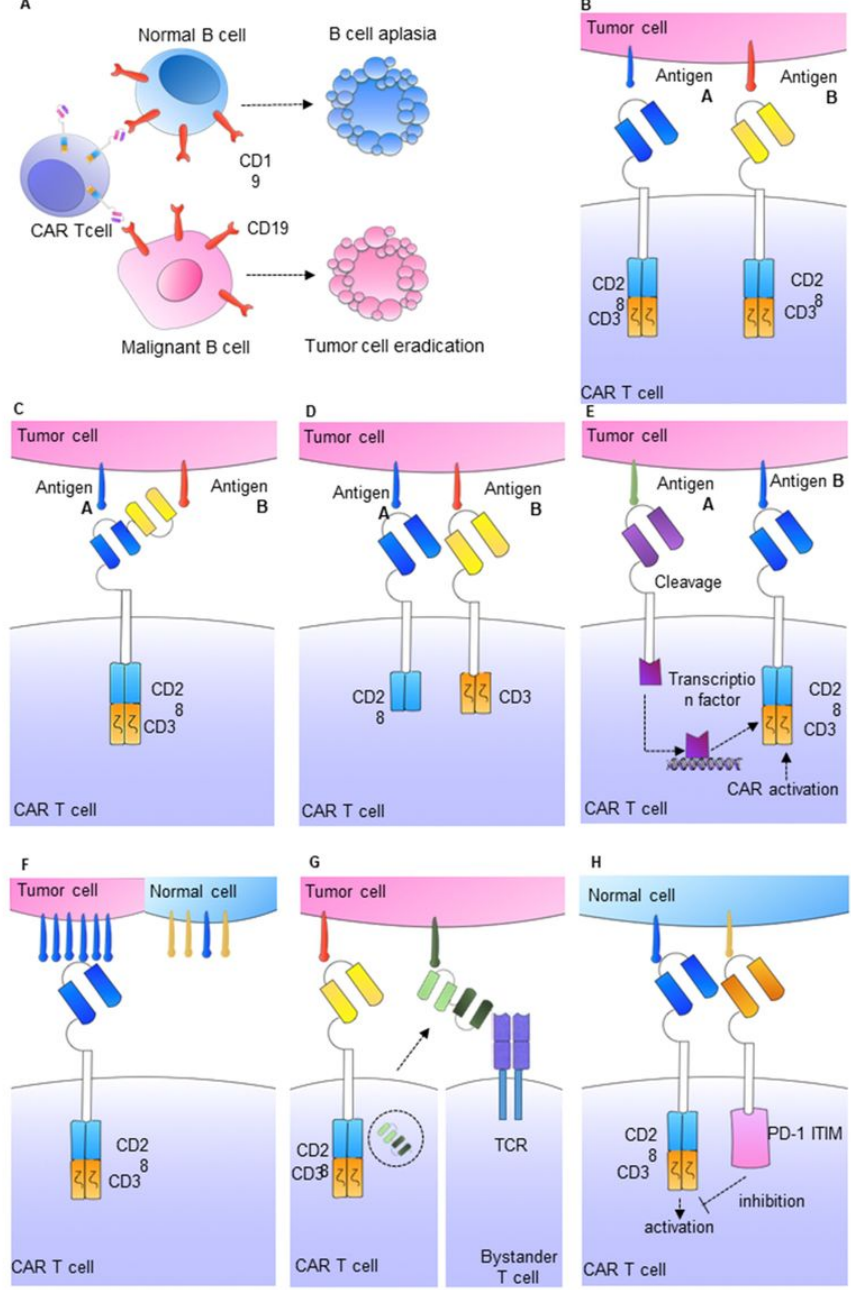

\section{Figure 3}

Multi-targeted CAR T cell. A. Beside tumor cells, non-malignant cells are targeted by CAR T cells because of common antigens expressed on malignant and non-malignant cells. This complication leads to off-target toxicity; $B$. In synNotch CAR T cells, the binding of " $A$ " antigen to synthetic Notch receptors leads to the release of a Notch transcription factor to the nucleus and subsequent induction of CAR expression against the "B" antigen; $C$. The split CAR is separated into two non-functional receptors. The co-stimulatory and signaling domains stay in two different receptors, harboring different scFvs and targeting different antigens. Thus, the entire activity of CAR T cells depends on the simultaneous recognition of both antigens; D. Tandem CAR T cells contain two scFv domains against the two target antigens that are joined together under the same intracellular signaling domain, and both antigen-binding domains can cause CAR $T$ cell activation by binding to own antigens; E. The recognition of normal cell-specific antigens by iCAR T cells inhibits CAR T cell activation because of signaling promotion of inhibitory-signaling domains that are integrated into non-malignant antigen-binding domains instead of costimulatory domains. CAR T cell activation against tumors requires the absence of non-tumor specific antigen; F. Affinity-tuned CAR T cells are predicated on the difference in the expression level of common antigens between tumor and non-tumor cells. G. Bi-specific T cell engagers (BiTEs) include two scFvs that are connected by a flexible linker. One of the scFvs binds to a particular TAA, and the other forms a specific bond with the invariant component of the TCR complex, CD3. H. PD-1 is a cell-surface molecule that controls the adaptive immune response. Targeting PD-L1 or PD-L2 by PD-1 leads to a signal induction that suppresses T cell proliferation, cytokine production and cytolytic function. 


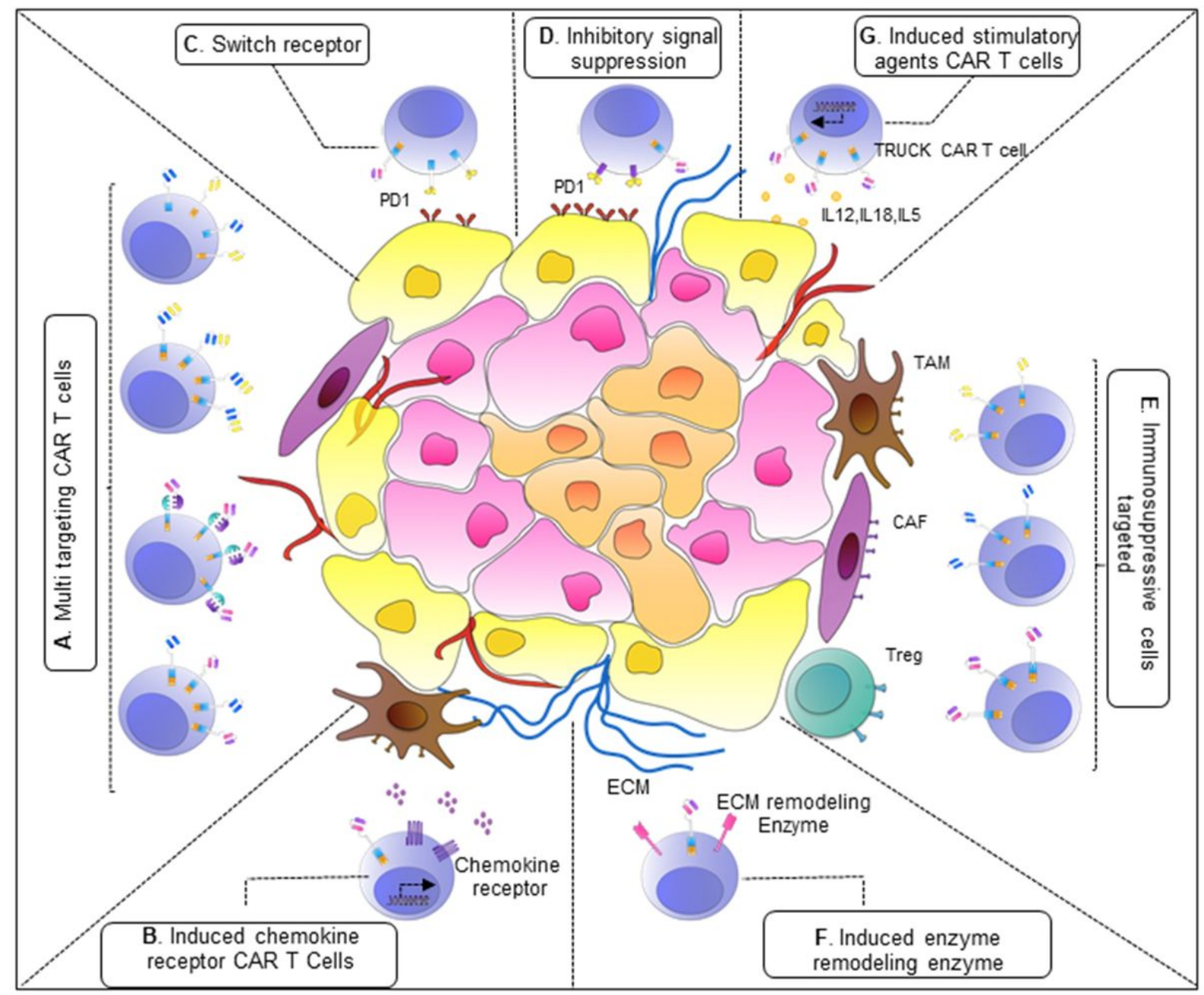

Figure 4

Overcoming strategies for immunosuppression and improving efficacy. CAR T cell efficacy is impeded by solid tumor heterogeneity, CAR T cell delivery to solid tumors, and their infiltration and homing. In addition, immunosuppressive cells such as TAM and Treg cells support the tumor by secreting suppressive cytokines that disrupt the T cell effector function. CAR T cells can be inhibited through checkpoint receptors such as PD-1 and CTLA-4, which are engaged by cognate ligands expressed on tumor cells or tumor-associated cells. Several strategies are adopted in CAR T cell therapy to overcome the challenges in targeting solid tumors. A. Multi-targeting approaches are implemented because of solid tumor heterogeneity. Examples of these methods are shown, such as inducing cells with different CARs, Zip CARs, Tandem CARs or Split CARs; B. CAR T cell trafficking can be improved through co-expression of induced chemokine receptors on CAR T cells, which directs the cells to the tumor location; C. Switch receptors can convert inhibitory signals present in the TME to stimulatory signals by replacing co-stimulatory domains in the receptor structures of the inhibitory molecules; D. \& E. Immune suppressive molecules and cells are targeted by CAR T cells; F. Co expression of induced enzymes that have a remodeling ECM function is implemented for overcoming CAR T cell infiltration; G. The fourth generation of CAR T cells is implemented to alter the immunosuppressive TME toward a stimulatory microenvironment through inducing coexpression of factors such as IL-12, IL-18 and IL-15. 